HIAS-E-55

\title{
Earnings, Savings, and Job Satisfaction in a Labor-intensive Export Sector: Evidence from the Cut Flower Industry in Ethiopia
}

\author{
Aya Suzuki \\ University of Tokyo \\ Yukichi Mano \\ Hitotsubashi University \\ Girum Abebe \\ Ethiopian Development Research Institute
}

October 2017

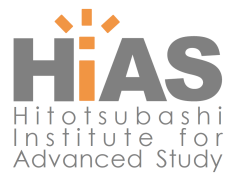

Hitotsubashi Institute for Advanced Study, Hitotsubashi University

2-1, Naka, Kunitachi, Tokyo 186-8601, Japan

tel:+81 425808604 http://hias.ad.hit-u.ac.jp/

HIAS discussion papers can be downloaded without charge from:

http://hdl.handle.net/10086/27202

https://ideas.repec.org/s/hit/hiasdp.html

All rights reserved. 


\title{
Earnings, Savings, and Job Satisfaction in a Labor-intensive Export Sector: Evidence from the Cut Flower Industry in Ethiopia
}

\author{
Aya Suzuki ${ }^{1}$, Yukichi Mano ${ }^{2}$, and Girum Abebe ${ }^{3}$
}

\begin{abstract}
:
While labor-intensive export-oriented industries typically bring positive economic benefits to countries through employment generation, the effects of these industries on various aspects of workers' welfare have not been formally studied very well. This paper considers the case of the cut flower industry in Ethiopia to provide such quantitative evidences. Based on the propensity-score matching and doubly robust estimations to facilitate rigorous comparisons, we find that production workers in the cut flower sector earn significantly more than similar workers in other sectors, most probably due to the flower farms' interest to reduce costly worker turnovers. In addition, the cut flower industry workers save more regularly than workers in other sectors who have similar characteristics, and the amount saved relative to the income level is also higher, after controlling for the frequency of wage payment and employment status. The subjective valuation of their jobs is also higher in the cut flower sector, particularly in terms of the income level, stability, and future prospect, but they are not necessarily more satisfied with the type of work they do. Risk-averse individuals are more satisfied in the cut flower sector and age is rewarded more, while work experience and math skills tend to reduce satisfaction levels more in the sector at this level of unskilled production workers.
\end{abstract}

\section{Keywords:}

Labor-intensive sector, Wage differential, Savings, Job satisfaction, Ethiopia

\section{JEL Codes:}

F63, F66, J31, O12, O14, O19

\footnotetext{
${ }^{1}$ University of Tokyo

${ }^{2}$ Hitotsubashi University

${ }^{3}$ Ethiopian Development Research Institute
} 


\section{Introduction}

The high-value export-oriented horticulture sector in developing countries has received attention in the past decades for its potential role in improving the welfare of rural population. Some earlier studies focused on farmers involved in the sector as producers (Jaffee and Masakure 2005, Minten et al. 2009, Maertens and Swinnen 2009, Suzuki et al. 2011), while more recent studies examine the impacts of employment in these sectors on the welfare of individual workers (Maertens et al. 2011, Mano et. al. 2011, Hermann and Grote 2015, Van den Broeck et al. 2017). Their results are mixed-some argue that such effects do not benefit the poor (Barron and Rello 2000, Trifkovic 2014, Ulrich 2014), while others argue that the sector contributes to reducing poverty (Maertens and Swinnen 2009, Maertens et al. 2011, Getahun and Villanger, forthcoming).

On another strand of literature, mainly from international economics, emergence of labor-intensive export sector, such as agro-processing and light manufacturing industry, are known to bring higher wages and other positive economic results to receiving countries via employment generation, earning foreign exchange or positive external economies (Borensztein et al. 1998, Markusen and Venables 1999, Barrios et al. 2005, Bwalya 2005, Li and Liu 2005, Gohou 2012, Gui-Diby 2014). One prominent effect is a wage increase specific to this export sector, exporter wage premia, found in the seminal work by Bernard and Jensen (1995) and others. The suggested explanations for this wage premia vary. Exporting firms may be more productive and able to offer higher wages (Tybout and Westbrook 1995, Isgut 2001), export premium may actually be the returns for the higher educational qualification of workers (Almeida 2007, Munch and Skaksen 2008), or may be paid in order to maintain a low turnover rate (Schank et al. 2007).

However, existing studies lack the following important elements. First, most of them fail to control several important worker characteristics, leaving a large room for unobserved heterogeneity behind the evidence of higher wages. Literatures from international economics mostly use firm-level aggregate data, and thus do not have any variables that control for workers' characteristics. Literatures from development studies use worker-level data, but do not consider some important variables that predict job acquisition and occupational choices, such as workers' ability and psychological factors, nor do they analyze the reasons why these sectors offer different opportunities for their workers. Second, most studies only examine worker incomes and do not consider other aspects of welfare, such as savings, remittances, or job satisfaction levels, which are also important from the development economics' perspectives. Third, 
although these sectors play a significant role in the early stages of economic development, rigorous empirical studies on developing countries remain limited. ${ }^{4}$ It is important to examine the cases of developing countries as poverty reduction is a key development objective and the industry structures may be different from those of developed countries.

This paper aims to understand the impact of participating in the laborintensive export sector on the welfare of individual workers, considering the case of the cut flower sector in Ethiopia. We particularly focus on the effects on workers' pay and saving behavior as well as their subjective valuations of quality of work in this sector. Using primary data collected from production workers in the cut flower farms and workers who have similar characteristics but are in other sectors, we examine whether financial performances, such as income, saving, remittance, contribution to households income, and subjective valuation of the quality of work are higher for the cut flower workers. In order to correct the possible selection bias, we employ propensity-score matching and doubly robust estimation methods. We find that the production workers in the cut flower sector earn significantly more than their counterparts in other sectors, both in terms of income and wage. We also find certain evidence that farms pay this wage premia in order to reduce worker turnover rates. Further, we find that workers in the cut flower sector save more regularly, and their saving rate, the ratio of the amount saved to the income, is also higher in comparison to their counterparts. The results are robust, including the hours worked, employment status, and frequency of payment. The total job satisfaction level is also higher for cut flower workers, particularly considering income level, stability of income, and future prospect.

In further analyses, we find that age is rewarded more in the cut flower sector in comparison to other sectors, but the effect of the number of years worked to the job satisfaction level decreases more rapidly for the cut flower industry workers in comparison to others. Risk-averse individuals are more satisfied with their jobs in the cut flower sector relative to people with the same level of risk averseness in other sectors, although they are paid less in comparison to other sectors.

Our contribution is threefold. First, we extend the current literature on exporter wage premium by providing evidence based on worker-level data, which allowed us to control for workers' qualities to the extent possible. We show that the

\footnotetext{
${ }^{4}$ Exceptions are Herrmann and Grote (2015), Hermann (2017), Van den Broeck et al. (2017), and Getahun and Villanger (forthcoming).
} 
export-oriented labor intensive industry, as represented by the cut flower sector in Ethiopia, offers higher income opportunities to workers in comparison to other sectors, holding the workers' qualities constant, even for the level of production workers who are at the bottom of the employment pyramid in the sector. We also provide some evidence for the reasons for this wage premia, relating the firm-level turnover rates and worker-level wages. Second, we find that participation in the high-value horticulture sector induces workers to save more often and larger amounts in comparison to their income level. To our knowledge, the impact of high-value horticulture sector on the saving behavior of workers has not been studied, and while saving behavior is a much studied topic in development literature (e.g., Karlan et al. 2014), its linkage to the working environment has not been examined. While the exact mechanism on what drives this behavior needs to be examined in further studies, anecdotal evidence suggests the role of peer effects within these labor-intensive environments. Third, we extend the study of the impact of export-oriented industry on subjective satisfaction of workers, going beyond the traditionally-studied outcome of income levels. The findings illuminate the type of workers who benefit (aged and more risk-averse) and the satisfaction with the work provided by these sectors.

The next section explains our hypotheses to be tested. Section 3 elaborately describes the cut flower sector in Ethiopia. Section 4 explains the data collection methodology. Section 5 discusses the estimation strategies employed and the estimation results are contained in section 6. Conclusions follow in section 7 .

\section{Hypotheses}

In order to examine the impacts of working in the cut flower sector, we pose the following five hypotheses. First, as the export wage premia holds, we predict that the cut flower sector offers higher wages to its workers in comparison to the workers' quality. The main reason for believing in the existence of wage premia is based on the fact that a high turnover rate among production workers is one of the main issues that cut flower farms encounter. From our interviews with managing directors of cut flower farms in 2013, we find that the turnover rate among permanent production workers was $14.4 \%$ in 2012 and increased to $20 \%$ in 2013. Note that these figures actually understate the true turnover rate of production workers as it only considers those who managed to remain for at least 45 days with the firm, those who became permanent workers. Anecdotes suggest that a considerable number of workers depart the farms within the first 2 or 3 weeks of employment. This high turnover rate among factory workers is also confirmed by Blattman and Dercon (2016), who find that a third of 
workers quit within the first month of employment in industrial jobs within their sample firms in Ethiopia.

Wage premia may be explained by a standard demand and supply model if the reasons for the premia are related to workers' utility, such as union effects, short-run immobility of labor, or compensating the bad working conditions of the job (“compensating differentials") (Krueger and Summers 1988). However, efficiency wage theories, modeled notably and formerly by Stiglitz (1984) and Katz (1986), apply when firms find it profitable to pay wages higher than the market wage relative to the workers' qualifications. Krueger and Summers (1988) explain four factors that induce firms to consider efficiency wage in particular: to minimize turnover costs, to raise workers' effort levels, to increase workers' sense of loyalty to firms, and to attract workers of higher quality. Among these possible reasons, we suspect that the hypothesis of minimizing turnover costs applies to the efficiency wage employed in the cut flower industry in Ethiopia, based on our anecdotal evidence of our fieldwork.5 Essentially, during our interview with the Ethiopian Horticulture and Agricultural Investment Authority, it was specifically mentioned that "To reduce turnovers, farms pay higher wages." We find that $9 \%$ of the farms surveyed in the flower census highlighted that labor turnover is the most important business problem that they faced. These firms chose turnover to be a more pressing problem than access to capital, market, or production technology. In order to minimize the costly turnover for the cut flower farms, we predict that the cut flower farms offer economic rents to their workers. As discussed later, this is also observed in other studies (Krueger and Summers 1988, Schank et al. 2007).

Hypothesis 1: The cut flower sector offer wage premia to its workers in comparison to workers of similar qualifications in other sectors.

Second, we predict that the previous turnover rate of flower farms would affect the wage as farms attempt to attract and retain workers by offering higher wages. The result may also confirm the relevance of efficiency wage theory in this sector.

Hypothesis 2: Among the cut flower farms, wage is higher in farms which previously had higher turnover rates, holding the quality of workers constant.

\footnotetext{
${ }^{5}$ There are supervisors in every section closely monitoring the production workers, and shirking is not a major issue (Mano et al. 2011).
} 
Third, as the cut flower sector provides stable employment opportunities, this may allow workers to plan for the longer run (Mullainathan and Shafir 2013) or form an informal savings club with colleagues, while taking advantage of the reduced transaction cost and peer pressure. Thus, we predict that cut flower workers tend to save more. Fourth, exporters operating in developing countries generally offer better working conditions in comparison to local firms. 6 We predict that the level of job satisfaction is higher for the cut flower industry workers.

Hypothesis 3: Working in the modern stable sector, cut flower industry workers tend to save more than their counterparts.

Hypothesis 4: The cut flower industry workers are more satisfied with their jobs, particularly in terms of stability.

Finally, job opportunities are often limited in developing countries and many people are self-employed. While employed workers tend to earn stable and relatively high incomes, self-employed workers may enjoy other aspects of their jobs, such as self-independence in the equilibrium. For instance, emerging evidence from labor market studies in Ethiopia has shown that formal employment in industrial jobs is less preferred to self-employment (Franklin 2014, Blattman and Dercon 2016).

Hypothesis 5: Self-employed workers are more satisfied with their jobs, particularly in terms of self-independence. Employed workers earn stable and relatively high income, partially compensating for the lack of self-independence.

We test these empirical hypotheses on the primary data of workers that we collected in Ethiopia.

\section{Cut Flower Sector in Ethiopia}

The cut flower sector in Ethiopia is one of the typical labor-intensive export-oriented industries brought to developing countries by globalization seeking lower wages. It has

\footnotetext{
${ }^{6}$ Cut-flower production is exclusively destined for the export market in developed countries. In the destination markets, consumers are increasingly wary of the conditions under which labor intensive products are being produced in developing countries. The growing awareness of customers and the vocal presence of labor and environmental campaigners have significantly induced multinational firms to voluntarily introduce high levels of labor and environmental standards in their production sites in developing countries (e.g., Henson and Rearcon 2005, Riisgaard 2009).
} 
experienced a significant growth starting from the first decade of the 2000s, following its neighbor Kenya, which ranks first in supplying cut flowers to the European markets. The export value of Ethiopia increased from 0.4 million USD in 2000 to 245 million USD in 2013/14 (Ethiopian Horticulture Development Agency 2015), and the number of firms surged from 5 in 2002 to 75 in 2013. The rapid growth was due to a strong government support, which provided many incentives for the investors in this sector, such as exemptions from taxes for inputs, lower land rental fees with basic utilities, facilitation of trade logistics and subsidy of air freight to main markets using the national carrier, and special loans provided by the Development Bank of Ethiopia (Mano and Suzuki 2015, Schaefer and Abebe 2015).

The development of this sector created a new labor market (Mano et al. 2011). Figure 1 shows the change in the average size of a cut flower firm in Ethiopia, using our primary census data of cut flower firms over the years. On an average, each firm hires approximately 500 workers. As a comparison, we also plotted the average number of workers for general Ethiopian firms and large firms (more than 100 employees) based on the World Bank Investment Climate data of 2011. It shows the contribution of the flower sector in employment opportunities. Production workers, who are unskilled workers, share $92.1 \%$ of the total employment in 2013. Considering that majority of the production workers are female workers with very limited education and alternative job opportunities, this sector appears to have contributed significantly to poverty reduction.7 The unemployment rate for female workers was $32.5 \%$, while that for all workers was 15.9\% in Ethiopia in 2012 (Central Statistical Agency, 2013). The percentage of full time female workers in a general Ethiopian firm was $33.9 \%$, while it was $71 \%$ for the production workers in the cut flower sector (using our firm survey of 2007).

\section{(Figure 1 around here)}

In a typical firm, production workers, generally employed locally, lie at the bottom of the worker pyramid, and are in charge of planting, spraying, harvesting, grading, and packing flowers for export. These tasks are not challenging but often require team work. To be adept in the specific tasks and fast in completing the work, time and experience is required. Losing one production worker equates to losing more

\footnotetext{
${ }^{7}$ In Ethiopia, all the export flowers are produced by large-scale flower exporting firms. As of 2015, no major role was played by smallholder farmers, unlike Kenya, where smallholders planted various flowers using a part of their agricultural plots for sales.
} 
worker and it lowers the team's production efficiency. Hjort (2014) demonstrated various levels of production efficiencies of team work using the cut flower industry of Kenya. The production workers are paid fixed wages per day or per month and are also constantly monitored by supervisors, reducing room for moral hazards. These workers are paid in cash and not through banks. Above them, supervisors oversee the work done by these production workers. These supervisors may be internally promoted from the role of production workers or hired by the firms directly. Several non-production workers who are employed from outside have bachelors' or masters' degrees in horticulture sciences. Above them are farm managers, who are more educated, and other white collar workers, such as accountants and administrators who work in the office. Labor poaching is not observed at the level of production workers, while it is common at the level of supervisors and managers. We focus on production workers in this study as they account for the majority of workers and are more likely to be impoverished.

\section{Data Collection}

We collected census of the flower industry in 2007, 2010, 2012, and 2013. Further, from January to March 2013, we conducted primary survey on workers of the cut flower sector. Cut flower farms are located around the capital city of Addis Ababa due to the proximity to the international airport and the high altitude, which is suitable for growing flower varieties with large buds. In order to draw random samples of production workers, we used a stratified sampling technique. First, we divided all the cut flower farms in Ethiopia into five groups, based on the index we created according to the socio-economic conditions of the nearby wereda (district), which are population, percentage of urban area, percentage of economically active people, and percentage of housing with water access, using the wereda-level information from the 2007 Population and Housing Census of Ethiopia with each element receiving the same weight. In each group, there were approximately 15 farms. Further, we randomly selected a few farms from each group, totaling to 10 farms. We visited these farms, requested a list of workers, and randomly selected approximately 15 production workers for the interview from the list. We ensured that the gender ratio corresponds to the real situation in the respective farm. The total number of production workers was 142.

Selecting samples for the comparison group was a challenging task. As our purpose was to examine the effect of working in the cut flower sector, in order to select people in the comparison group, we were required to choose individuals who had 
socio-economic characteristics very similar to the production workers in the cut flower sector, but were not in the same sector. Selecting people randomly from the nearby locality was not appropriate as those people may not have attributes similar to the production workers. In the rural area, people may be fairly homogeneous in terms of their potential of being employed, but some of the farms were located in small towns where there were various job opportunities, and thus different types of people. Thus, we relied on the production workers' own network. We requested production workers to introduce us to some of their friends who were not in the flower sector but had characteristics similar to them, particularly in terms of their education level, which is known to be an important determinant in the job market, as well as age and gender. ${ }^{8}$ From the list of friends, we randomly selected people for the interview. When none of their friends were available for the interview, we additionally selected people from the locality and ensured that they had similar observable attributes to our production worker group. The number of samples collected from the locality, rather than through the friends' network, was only 11 out of the total 159 samples in the comparison group.

Among the comparison group, we excluded 19 samples who were unemployed and 5 samples who were in school. Although they may represent the counterfactual state of production workers in the cut flower sector accurately, as many of our variables of interest are related to income, using many samples without income in the control group may yield biased results. Therefore, our estimates of welfare effects of the presence of the cut flower sector are likely to be modest, and should be considered as lower bounds. Among the remaining 135 samples, 76 were hiredworkers, 12 were farmers, 39 were self-employed, and 8 had multiple jobs (3 hiredworkers and farmers, 2 hired-workers and self-employed, and 3 farmers and selfemployed). The typical jobs for the hired-workers were house maid, beauty salon worker, waiter, laundry worker, factory worker, hired agricultural laborer, construction worker, government organization employee, guard, hotel receptionist, café cashier, and so forth. There were 13 factory workers who were most comparable to the production workers in the cut flower sector in terms of the type of work. This shows that our control group comprises of people with various types of jobs available in the locality.

In addition to the standard socio-economic characteristics, such as age, gender, schooling, and income levels of these respondents, we also requested the respondents a subjective valuation of their jobs. We asked the respondents questions on

\footnotetext{
${ }^{8}$ To control for the variation in abilities, which are not fully captured by the education level, we also use the math test score in the following analyses.
} 
five aspects: 1) income level, 2) stability of income, 3) type of work engaged, 4) future prospect, and 5) self-independence. The respondents were expected to rate their satisfaction levels using 5 scales, from 1 to 5 , where 1 referred to being very unhappy and 5 referred to being very happy. We also computed the total score with a maximum of 25 .

Further, we collected information about the respondents' psychological traits, namely risk preferences, competitiveness, and overconfidence. These psychological traits appear particularly relevant for stability of income or in promoting competition among employees, which typically characterize labor-intensive mass-production enterprises. In order to elicit risk preferences, we conducted a game with real payoffs, following the popular method pioneered by Tanaka et al. (2010). We asked the respondents to choose either project $\mathrm{A}$, which receives a certain payoff, project $\mathrm{B}$, which yields a probabilistic payoff of a certain amount (8 Birr), or 0 each at $50 \%$ probability. We prepared eight games, and the certain payoff in project A increases as we go down the list of eight games (Figure 2). The expected payoff for project B remains the same in all the eight games. The expected payoffs of these projects are equalized at game 4 , and from then onward, it is higher for project $\mathrm{A}$. Thus, earlier the respondent switches from project $\mathrm{B}$ to $\mathrm{A}$, the more risk averse the person is. We created an index between one and nine, nine being the most risk averse.

\section{(Figure 2 around here)}

In order to measure how competitive a person is, we undertook a simple math test, following a popular method (Niederle and Vesterlund 2007, and Balafoutas et al. 2012). The respondents were asked to solve the addition of two 2-digit numbers within two minutes and were graded according to the number of correct answers. We chose this simple test such that our respondents, who had few years of schooling, were able to solve at least some of the easiest questions. We conducted these tests three times, and each time a different set of problems with real payoffs were provided.

In the first round, the respondents were provided piece-rate rewards of 1 Birr per correct answer, which is approximately $5 \%$ of their daily wage. In the second round, the respondents were provided relative rewards of 3 Birr per correct answer if their score was the highest among the group of five people, but none if they ranked second or lower. The four other members were chosen randomly from the samples and 
had previously completed the interview. ${ }^{9}$ The respondents did not know who the other members were. They were only informed that the other members were also the respondents of this survey (i.e., thus had traits similar to the respondent). In the third round, the respondent was provided a choice of three alternative reward methods, without being informed of their performance in the previous rounds. The first method follows the first round reward (absolute piece-rate grading), the second method follows the second round reward (relative grading and winner-takes-all), and the third method is a more moderate version of the relative grading (the top receives 2 Birr per correct answer, $2^{\text {nd }}$ and the $3^{\text {rd }}$ receive 1 Birr per correct answer, and otherwise receives zero). We used the respondent's choice of payment method in the third round to measure their competitiveness. If the person chose the first method of absolute grading, the person was considered "not very competitive" as they preferred to be graded only by their own score, not relative to other people. Similarly, if the person chose the second method (winner-takes-all), they were considered "the most competitive." The person choosing the third method was in between. Their experience of solving these problems from the previous rounds could influence their choice of payment. For example, those workers who thought that their scores were high may choose the most competitive payment method, while those who thought to have scored low may choose a piece-rate payment method. Here, it is important to note that we did not inform the respondents on how well they actually scored (neither in absolute scores nor in ranking) after each round. Thus, the effect of previous experience on the payment choice of the third round is only based on their own self-evaluation and not reflecting any new information about their actual ability in answering these problems.

In order to control for the difference in this type of self-evaluation, we also measured the degree of overconfidence. Prior to conducting the math test, we asked the respondents about their prediction on how many correct answers they would mark and what would be their rank among the group of five in the relative grading rounds. We used the difference between the former prediction and the actual number of correct answers to indicate overconfidence in score estimation, while we used the difference between the latter prediction and the actual ranking to measure the overconfidence in the rank estimation. The former can be considered as overconfidence in absolute evaluation and the latter as overconfidence in relative evaluation (Kamas and Preston 2012).

\footnotetext{
${ }^{9}$ For the previous respondents, we conducted the tests for several workers to first obtain their test scores and used these scores to complete their questionnaires subsequently.
} 
Further, we utilized our primal data which was separately collected from all the cut flower farms in Ethiopia in 2012 to control for the characteristics of farms that workers belonged to, in particular, the turnover rate and the number of workers. In addition, we also use public data, such as the 2007 Population and Housing Census to control for wereda-level information.

\section{Estimation Strategy}

Our aim is to examine how the emergence of the cut flower industry has impacted the welfare of workers. Individual workers' status of whether they are involved in the cut flower sector may also be subject to selection bias. Although we have carefully selected the comparison group such that they have similar observable characteristics as the production workers, some selection bias may remain. For example, production workers in the cut flower sector may perform better financially as they are more diligent. Similarly, cut flower farms may select and retain workers who are more capable and dedicated. We control for the potential unobservable ability of workers by including the score of the math test we conducted during the interview. Solving a number of cumbersome math questions require not only numeracy but also diligence. Further, in order to reduce the differences between the treatment and control groups based on observable characteristics, we employ several methods.

First, we conduct a propensity score matching (PSM). Under the PSM, we first estimate the probability that each observation belongs to the cut flower sector based on the worker's characteristics and match a production worker with a worker in the comparison group who has a similar probability. The average of the differences in the outcome variables between the matched samples is the treatment effect. In order to estimate the propensity score, we included variables which were considered to be important for job acquisition, such as the worker's background, ability, and personal characteristics, and which are found to be statistically and significantly different between the control and treatment groups. To match, we attempted several different methods and report the results of two methods among them, Caliper matching and Kernel matching, as they reduce the bias the most in our case. Caliper matches an observation in the treatment group with an observation in the comparison group which has the closest propensity score within the specified maximum tolerance distance, while Kernel matching creates hypothetical observations using the information from the control group to match the observation in the treatment group. Each matching method has both advantages and disadvantages, and we report how significant bias was reduced through these matching methods. 
Second, while the PSM removes systematic observable differences between the treatment and control groups, it reduces efficiency in estimation (Hahn 1998, Heckman, Ichimura, and Todd 1998). Thus, we also use an inverse propensity-score weighting regression, which was originally proposed by Robins and Rotnitzkey (1995) and developed further by Hirano, Imbens, and Ridder (2003) among others. In this method, the inverse of the propensity score is used as weights to run regressions of the outcome variable. This is also known as a "doubly-robust" estimator as only one of the models (treatment or outcome) needs to be correctly specified to achieve consistency in estimation (Wooldridge 2007). As our aim is to estimate the treatment effects on the treated, we use the weight which is equal to one for treated observations and $p s(x) /(1-p s(x))$, where $p s$ refers to the propensity score for the control observations (Hirano and Imbens 2001).

Further, in order to guarantee a sufficient overlap in propensity scores of the two groups, we also trim our samples to conduct the inverse propensity-score weighting regressions. Among the various methods to trim the samples (e.g., Dehejia and Wahba 1999, and Heckman et al. 1997, 1998), we rely on Crump et al. (2006) which compute the optimal cut-off point from estimated propensity scores as their method is derived from rigorous theory. ${ }^{10}$ Based on this, we use samples with propensity scores in the interval of $[0.1609,0.8391]$, which meant excluding 26 observations. ${ }^{11}$

\section{Estimation Results}

Table 1 shows the summary characteristics of the two groups. While we observe similarities, we also find some variables that are statistically different between the two groups. We control for these differences in the following analyses. We find that on an average, the respondents are in their mid to late $20 \mathrm{~s}$. Approximately $80 \%$ of them are female, which is a characteristic of the cut flower sector, particularly at the production worker level. The workers have approximately 6 years of education, while their mothers and fathers have approximately 1.5 and 2.5 years of education, respectively. As aimed in our sampling method, the number of years of schooling is not different

\footnotetext{
${ }^{10}$ Other studies, such as Chen et al. (2009) and Deininger and Liu (2013) rely on this trimming method.

${ }^{11}$ For a robustness check, we also conducted the same estimations using the full sample and the trimmed sample based on the "maxima-minima" criteria (Caliendo and Kopeinig 2008). These yielded very similar results in comparison to what was reported below both, in terms of statistical significance and magnitudes of coefficients.
} 
between the workers in the treatment and control groups. However, we also find that the average math score is higher for the control group. Approximately $73 \%$ of the production workers are from farming households. The average number of years worked in the current job is 3.5 years for the production workers, while it is 5.3 years for the comparison group. Whether the person is born in the village and the number of years they are living in the current village is not different across the two groups. Psychological traits, such as risk averseness, competitiveness, and overconfidence, show interesting differences. While the two groups are not different in terms of risk preferences, production workers in the cut flower sector are more competitive, but less overconfident in terms of relative ranking estimations.

\section{(Table 1 around here)}

On an average, we find that financial performance between these groups is not significantly different (Table 2). Typically, these workers earn approximately 730 Birr (about 34.7 USD) per month. The daily income is approximately 24 Birr (1.15 USD) for the cut flower worker, while it is 23.9 Birr (1.13 USD) for the comparison group. The daily household income per capita is 16 Birr (0.76 USD) for the cut flower worker and 18.3 Birr (0.87 USD) for the other group, indicating that most of them live below the international poverty line of 1.25 USD per day. The cut flower production workers tend to save more often than their counterparts and the difference is statistically significant. Their saving rate, defined as the amount saved over the income level, is $3 \%$ higher for the cut flower workers in comparison to their counterparts, but the difference is not statistically significant. The frequency of remittance, household income, contribution to household income, and percentage of food expenditures are not different between these groups. Distribution of income is depicted for each group in Figure 3. We observe that although the average income is comparable, the production workers' distribution of income is tighter around the mean, while the income of the comparison group has a wider spread, most likely owing to the comparison group including a variety of sectors with varying amounts of economic rents.

(Table 2 around here)

(Figure 3 around here)

(Figure 4 around here)

The diamond-diagram in Figure 4 shows that the average job satisfaction level 
is higher for the production worker group than the comparison group in all aspects. Particularly, cut flower production workers seem to be more satisfied in terms of the stability of their job and self-independence.

\section{PSM Results}

In order to analyze their performance more closely, we conducted a propensity score matching and inverse propensity-score weighting regressions. To estimate the propensity score of working in the cut flower sector, we included variables that matter in job acquisition, such as schooling, ability, family background, and certain psychological traits and used the model in Table 3. Some variables, such as age, gender, math score, whether parents are farmers, whether they were born in the village, and certain psychological factors, are significantly different between the two groups. In order to choose a matching method that reduces the bias the most, we adopted several matching methods as presented in Table 4. As shown after matching, the number of covariates that are statistically significant between the two groups becomes zero in all the methods. However, when we examine the extent to which the covariates explain the treatment status, we find that Caliper matching minimizes the difference in covariates between the two groups (low pseudo R2 and high p-value). Further, the mean bias is the smallest for the Caliper matching method and is less than $5 \%$, which is a commonly used threshold (Caliendo and Kopeinig 2008). Thus, Caliper matching provides the best balance. We report the results of Caliper matching and Kernel matching in Tables 5 and 6 respectively, and depict the histogram of the propensity scores between these groups (Figure 5). ${ }^{12}$ Considering these, our sample appears to be very well balanced after matching.

\section{(Table 3 around here) \\ (Table 4 around here) \\ (Table 5 around here) \\ (Table 6 around here) \\ (Figure 5 around here)}

Our PSM results show that while the financial performance between the two groups was not different before the workers obtained the current job, their income level

\footnotetext{
${ }^{12}$ For models using the logged income, farmers with negative incomes (six observations) were excluded.
} 
and saving status significantly differ currently (Table 5). Under Caliper matching, none of the variables are significant in panel A, which reports the status before their current jobs. Considering Kernel matching, the annual income and whether they save are negative for the cut flower production workers in panel A. However, in panel B, which reports the current status, the $\log$ of annual income is positive and statistically significant at 5\% level for Caliper matching and at $1 \%$ level for Kernel matching. Whether the workers save is also statistically significant for both the matching methods, and the saving rate, defined as the amount saved monthly divided by the monthly income of the respondent, is positive and statistically significant for both. These findings suggest that assuming that only observable differences are important, ${ }^{13}$ if we randomly allocate workers to the cut flower sector, they will earn more and save more often.

Table 6 shows the PSM results for the job satisfaction level for these workers. We find that most of these coefficients are not statistically significant but are positive. In the aspect of stability, the Kernel matching result shows that the cut flower workers are more satisfied than their counterparts in other sectors.

\section{On Income and Wage}

For more robust analyses, we conducted an inverse propensity-score weighting regression. Here, we limited our interest to the log of income, log of wage, whether they save, and the saving rate, which were found to be statistically significant in the PSM analyses, and the various job satisfaction levels. In Columns (1) to (4) of Table 7, we show four models for the log of income and log of wage, with and without the status of employment (i.e., hired or self-employed). We show the results from trimmed samples for brevity, but the results using the full sample and trimmed using the maxima-minima criteria show similar results.

\section{(Table 7 around here)}

First, we observe positive effects of cut flower dummy on all the models, which indicate the presence of exporter-wage premia. This supports Hypothesis 1. In terms of income, the cut flower workers earn $44 \%$ more than their counterparts in other sectors, and $26 \%$ more than the hired workers in other sectors. In terms of wage, the

\footnotetext{
${ }^{13}$ Note that we also control for certain potentially unobserved psychological characteristics and abilities in our propensity score estimation.
} 
cut flower workers earn $20 \%$ higher than the hired workers in other sectors. It is noteworthy that this wage premia was confirmed, holding other variables constant that are important for wage, such as schooling, ability, experience, psychological factors, payment methods, and wereda-level labor market conditions. This finding is consistent with existing literatures which examined the existence of exporter wage premia (Schank et al. 2007).

While examining the reason why the cut flower sector is offering wages higher than the market wage relative to workers' qualities, we used data from our firmlevel survey to estimate whether the past turnover rates of farms have any effects on the wages of production workers. In the survey, we asked the managing directors of cut flower farms for their past turnover rates and this ranged from $2 \%$ to $70 \%$ in 2010 . The result in Column (5) of Table 7 shows that indeed, the past turnover rate is positive and statistically significant at $1 \%$ level. In terms of magnitude, a $1 \%$ increase in the turnover rate leads to a wage increase by 3.3\%. This supports Hypothesis 2. Although the tasks that these production workers are assigned are relatively simple, such as cutting, sorting, or packaging roses, to be adept at these tasks and to increase efficiency, time and experience is required. As team work is often required, losing one experienced production worker lowers the production efficiency of the entire team. It is generally the case that during the first several months of employment, production workers go through on-the-job training. It is costly for the farms to train the workers as their supervisors and some of the co-workers are required to spend time with the new workers. The negative and statistically significant coefficient on the number of cut flower workers in the wereda also suggests that the farms can afford to pay smaller wage premia in areas where a large pool of experienced workers are available owing to lower replacement costs.

Several significant results were also obtained from other control variables. We find that more years worked and higher math scores lead to higher income and wages. While the number of years of schooling does not appear to be important in differentiating the wage level for the production workers, the actual skills (math score) does matter for the wages. We also find that when payments are made more frequently, higher is the annual income. The hours worked is negatively related to wages. Considering the employment status, the base category is a group of workers who are self-employed, including farmers. We find that income and wages are higher for employed workers in comparison to self-employed workers, by as much as $57.6 \%$ (Column (2)) and 50.4\% (Column (4)), respectively. 


\section{On Saving Behavior}

In Table 8-1, we examined the effects of the cut flower sector on saving behaviors. The probability of saving is higher for the cut flower workers by approximately 21.1$25.0 \%$ than their counterparts in other sectors (Columns (1) and (2)). We find that the saving rate, defined as the amount saved over the income level, is also significantly higher for the cut flower sector by approximately 4.6-6.3\% (Columns (3) and (4)). These results confirm Hypothesis 3. If an individual works in the cut flower sector, they tend to save more often and a more amount relative to the income level, controlling for the frequency of payment. The probability of saving and the saving rate are higher for younger workers, which is consistent with the life-cycle model (Modigliani and Brumberg 1954, 1979, Deaton 1992). Those with more years of working experience tend to save more often. The more number of hours people worked per month, more often people saved. We also find that the saving rate of the selfemployed workers is higher by $6.2 \%$. However, in interpreting this result, one needs to take into account the observation that the self-employed workers in developing countries often manage household and business expenses together and do not separate accounting (Drexler et al. 2014, Abebe, Tekle, and Mano 2016). Thus, it is possible that those self-employed workers may attribute positive business profits as their personal savings. It is notable that among the hired workers, the saving rate of the cut flower industry workers is higher by $6.3 \%$.

As this higher saving behavior among the cut flower industry workers may be due to their higher income levels, we conducted the same analyses for the subsamples of lower and higher income groups, using the threshold of the mean income (Table 82 ). It is possible that cut flower workers can afford to save as they have higher incomes. However, we find that the cut flower dummy is significant only in the lower income group (Columns (1)-(2)). This suggests that the cut flower sector is inducing their lower-income workers to save more relative to their counterparts in other sectors. We also find that the number of years of working experience positively affects the saving behavior of only the lower-income group.

\section{(Tables 8-1 and 8-2 around here)}

A higher frequency of saving in the cut flower sector is consistent with the PSM results and is rather puzzling why people tend to save more if they are allocated to this sector. Higher probabilities to save and higher saving rates are obtained by holding income levels, frequency of payment, and employment status constant. Thus, 
there appears to be something about the cut flower sector which motivates people to save more. Based on our field observation about their working environment, we suspect that this is partly due to the high degree of social interaction among workers in the cut flower sector. The workers meet each other every day from $8 \mathrm{am}$ to $4 \mathrm{pm}$, work side-by-side through all the working hours, eat lunch together, commute together, and possibly live in close proximity with each other. This type of communication is typical of a labor-intensive mass production industry, while in other sectors, people tend to work in smaller groups or independently. Recent studies found that social interaction within firms affect the productivity of workers (e.g., Bandiera et al. 2005, 2010, 2011, Hjort 2014) and we suspect that it also affects their behavior outside the workplace.

We can consider several potential mechanisms of how these social interactions lead to higher saving rates. First, higher social interactions may increase trust among people, facilitating the Rotating-Savings-and-Credit-Association (ROSCA) type of savings. In Ethiopia, a ROSCA called Ekub is very common. People form groups to save a certain amount of money in a common pool and rotate the turn to receive the savings among the members. For this type of saving to functionally work, it is not difficult to imagine that social interactions among workers are essential. Indeed, Getahun and Villanger (forthcoming) find that cut flower employment facilitated network formation, including Ekub membership, among workers within the farms. Second, high social interactions may work as a good reminder to save (e.g., Karlan et al. 2014, Abebe et al. 2016). As workers receive payments together on the same day and in cash, it is likely that they talk about the payment and how they expect to spend it. In many farms, workers need to sign payroll sheets to receive wages and they can observe how much others receive through these sheets. Individuals may be reminded to save if they realize that their friends save as well. Third, social interaction may go beyond a simple reminder and impose certain pressures on people to save if saving is considered to be a good behavior socially (e.g., Mas and Morretti 2009). Given that most of these workers are female and mothers of households, social pressures to act as good mothers may be high. In fact, in our interview, one of the workers mentioned that "Ekub is the best way to save because I feel equal to other colleagues." Saving the same amount with other colleagues gave the interviewee a sense of confidence that she is doing the right thing. Though these need to be tested formally to mention anything conclusive, social interactions between workers appear to have certain effects on the higher saving behaviors in the cut flower sector. 


\section{On Job Satisfaction Level}

Considering the impact on job satisfaction levels, we find that the total score is higher and statistically significant for the cut flower workers by approximately 2.1 point out of the full mark of 25 points (8.4\%) (Column (6) in Table 9), confirming Hypothesis 4. More specifically, workers are more satisfied in terms of their income level, stability of income, and future prospect (Columns (1), (2), and (4), respectively). Particularly, the magnitude and statistical significance level are high for the aspect of stability. Stability of income may be related to the saving rate as the workers' regular income exceeds some threshold level above which (they feel) the workers can afford to save constantly (Friedman 1957).

\section{(Table 9 around here)}

In addition to the cut flower dummy, we find that as individuals work for more number of years in one place, they tend to be less satisfied with selfindependence (Column (5)). The number of hours worked per month is positively correlated with many of the aspects of job satisfaction.

Another notable finding is that being employed reduces job satisfaction levels in most of these aspects. The total satisfaction level is lower for these hired workers by 2.8 points out of 25 points $(11.4 \%)$ than self-employed workers (Column (6)). It is striking to compare these results with the income regression in Table 7, which indicates that income levels are higher for these hired workers in comparison to self-employed workers. Thus, self-employed workers, though earn lesser than their counterparts, appear to be happier with their jobs, supporting Hypothesis 5. Combining these findings, this higher income by $57.6 \%$ (Column (2) in Table 7) may be considered as the compensating differential of disutility from being employed by someone else and giving up independence.

\section{Heterogeneous Effects}

Finally, in order to examine the heterogeneous effects of the cut flower sector on income and saving behavior, we report the coefficients of interaction terms between the cut flower dummy and corresponding variables from inverse propensity-score weighting regressions in Table 10. We find that older people tend to be rewarded more in the cut flower sector than other sectors. The contribution of age to income is approximately $3.2 \%$ more in the cut flower sector relative to other sectors. This result survives after controlling for firm-specific experience, holding the years of worked at 
the same place constant. This suggests that the cut flower sector also provides an important earning opportunity for older people.

\section{(Table 10 around here)}

We also find that risk averseness is rewarded less in the cut flower sector relative to the other sectors. This suggests that risk-averse people particularly prefer the stability of this sector and accept the jobs in other sectors only when they are

sufficiently compensated for the instability of other sectors. Considering the saving behavior, we find that the contribution of years worked at one place and math score to saving rate is less in the cut flower sector relative to other sectors. The number of household members, which negatively affected income and wage in Table 7, are positive for the cut flower industry workers. This possibly suggests that the cut flower farms offer a better working environment for mothers with children or more dependents.

The heterogeneous effects of the cut flower sector on job satisfaction levels are reported in Table 11. We find that the contribution of age and years worked to the satisfaction level on future prospect is lower in the cut flower sector in comparison to other sectors. Thus, longer the worker continues to work in the cut flower sector, they become less satisfied with the future prospect relative to workers in other sectors, probably as the tasks of the production workers are simple and tedious, and as they are not satisfied with the fact that they did not get promoted to the supervisor's level. This may be another explanation for the high turnover rate in this industry. We also find that among the cut flower workers, those who have higher math ability are less satisfied with their income level. This is also possible considering the type of work that they engaged in at the production worker's level.

\section{(Table 11 around here)}

Among the psychological traits, the contribution of risk averseness to job satisfaction level is higher in the cut flower sector. Particularly, its contribution is significantly higher in the aspects of income level, stability of income, and selfindependence. As the cut flower sector provides higher income and stable employment opportunity, risk-averse individuals may be happier in this sector in comparison to other sectors. It is interesting to compare this result with the previous table, which shows that risk-averseness is awarded less in the cut flower sector. Although risk- 
averse individuals are paid less in this sector, they are more satisfied with the job owing to its stability. The frequency of payment also contributes more to the satisfaction on income level and stability in the cut flower sector than in other sectors. These findings on heterogeneous effects show that the cut flower sector provides benefits, particularly for older workers and those with more household members, and offers good working environments for more risk-averse workers. However, workers with higher skills or more experience appear to be less satisfied in comparison to their counterparts in other sectors.

\section{Conclusion}

In this paper, we analyzed the impacts of participating in the cut flower sector as an employee relative to working in the other sectors on individual workers' financial welfare. Utilizing individual workers' data, we find that the cut flower sector offers higher wages relative to other sectors in the locality, holding the workers' qualities constant. Further, we find that cut flower wage premia increases as the past turnover rates increase, suggesting that efficiency wage is employed in this sector in order to reduce worker turnover rates. The cut flower industry workers also save more regularly than their counterparts in other sectors, and the amount saved relative to the income level is also higher for the cut flower workers. We also find that this positive impact on saving behavior can be observed only for the lower-income group, indicating the sector's contribution to the welfare of the poor segment of the society. The workers' subjective valuation of their work is also higher for the cut flower workers, particularly on their income level, stability of income, and future prospect. However, they are not necessarily more satisfied with the type of work that they engage in when compared to their counterparts in other sectors. The high wage appeared to be driven by the need for flower farms to maintain a stable group of workers in order to sustain supply to the global market. On the other hand, the more number of years worked in the cut flower sector has greater impact of reducing the job satisfaction level relative to other sectors. In order to retain the experienced yet less satisfied production workers, farms offer higher wages relative to other sectors.

While our study showed that an export-oriented labor-intensive industry can improve the welfare of the poor and change their saving behavior, there are several areas that need to be further studied. First, our analysis is limited only to the welfare of workers themselves, and may thus underestimate the full impacts. For example, we could expect to see impacts on the resource allocation within the worker's household, such as investment in children's education or changes in the bargaining power of wives 
within households. As this sector is dominated by female workers, it is likely that employment opportunities in this sector have influenced the welfare of households as well as individual workers. Second, we did not examine what determines the survival of workers in firms in this sector. It would also be of interest to examine whether there are any systematic differences between those who exited the sector and those who continue to work in this sector. A certain level of worker turnover is healthy, and production workers rarely prefer to stay as production workers throughout their working life. In order to avoid persistent wage increments, firms are also reluctant to continue to employ aging workers in the same low-value adding tasks for a long period of time. The finding that flower workers save a higher proportion of their income in comparison to workers in other sectors and that older workers are less satisfied with working in the flower industry indicate that saving from the sector could present an opportunity for mutually beneficial separation between workers and firms. Indeed, in many low income countries where the financial sector is underdeveloped, personal saving is the main source of initial capital for workers to set up their own businesses. Further study is warranted to explore the extent to which saving from the sector has induced the formation of successful small businesses by stimulating workers to move out of wage-employment. Finally, it will be valuable to particularly examine the effectiveness of wage premium in reducing worker turnover and improving the productivity of the flower farms. These issues warrant further investigation in order to understand the full impact of the emergence of these sectors in developing countries. 


\section{References}

Abebe, G., B. Tekle, and Y. Mano. (2016). "Changing Saving and Investment Behavior: the Impact of Financial Literacy Training and Reminders on Micro-business." CSAE Working Paper Series 2016-08, Centre for the Study of African Economies, University of Oxford.

Almeida, R. (2007). "The Labor Market Effect of Foreign Owned Firms." Journal of International Economics 72: 75-96.

Balafoutas, L., R. Kerschbamer, and M. Sutter. (2012). "Distributional Preferences and Competitive Behavior." Journal of Economic Behavior and Organization 83: 125-135.

Bandiera, O., I. Barankay, and I. Rasul. (2005). "Social Preferences and the Response to Incentives: Evidence from Personnel Data." Quarterly Journal of Economics, 120(3): 917-962.

Bandiera, O., I. Barankay, and I. Rasul. (2010). "Social Incentives in the Workplace." Review of Economic Studies 77(2): 417-458.

Bandiera, O., I. Barankay, and I. Rasul. (2011). "Field Experiments with Firms." Journal of Economic Perspectives, 25(3): 63-82.

Barrios, S., H. Gorg, E. Strobl. (2005). "Foreign Direct Investment, Competition and Industrial Development in the Host Country." European Economic Review 49 (2): 1761-1784.

Barron, M.A. and F. Rello. (2000). "The Impact of the Tomato Agroindusstry on the Rural Poor in Mexico." Agricultural Economics 23: 289-297.

Bernard, A.B. and J.B. Jensen. (1995). "Exporters, Jobs, and Wages in U.S. Manufacturing: 1976-1987." Brookings Papers on Economic Activity. Microeconomics: 67-119.

Blattman, C. and S. Dercon. (2016). "Occupational Choice in Early Industrializing Societies: Experimental Evidence on the Income and Health Effects of Industrial and Entrepreneurial Work." NBER Working Papers 22683, National Bureau of Economic Research, Inc.

Borensztein, E., J. De Gregorio, and J-W. Lee. (1998). "How does Foreign Direct Investment Affect Economic Growth?” Journal of International Economics 45 (1): 115-135.

Bwalya, S.M. (2005). "Foreign Direct Investment and Technology Spillovers: Evidence from Panel Analysis of Manufacturing Firms in Zambia." Journal of Development Economics 81(2): 514-526.

Caleido, M. and S. Kopeinig. (2008). "Some Practical Guidance for the Implementation of Propensity Score Matching.” Journal of Economic Surveys 22: 31-72.

Chen, S., R. Mu, and M. Ravallion. (2009). "Are there Lasting Impacts of Aid to Poor Areas?" Journal of Public Economics 93: 512-528.

Crump, R.K., V.J. Hotz, G.W. Imbens, O.A. Mitnik. (2006). "Moving the Goalposts: Addressing Limited Overlap in the Estimation of Average Treatment Effects by Changing 
the Estimand." NBER Technical Working Papers 330, National Bureau of Economic Research, Inc.

Deaton, A. (1992). Understanding Consumption. Oxford, Clarendon Press.

Dehejia, R.H. and S. Wahba. (1999). "Causal Effects in Nonexperimental Studies: Reevaluating the Evaluation of Training Programs." Journal of the American Statistical Association 94(448): 1053-1062.

Deininger, K. and Y. Liu. (2013). "Economic and Social Impacts of an Innovative Self-Help Group Model in India." World Development 43: 149-163.

Drexler, A., G. Fischer, and A. Schoar. (2014). "Keeping it Simple: Financial Literacy and Rules of Thumb." American Economic Journal: Applied Economics 6 (2): 1-31.

Ethiopian Horticultural Development Agency. (2015). Available at http://www.ehda.gov.et/

Franklin, S. (2014). Ethiopia Unemployment Report. Technical Report, International Growth Centre, London.

Friedman, M. (1957). A Theory of the Consumption. Princeton University Press, New Jersey.

Getahun, T.D. and E. Villanger. (forthcoming). "Labour-Intensive Jobs for Women and Development: Intra-Household Welfare Effects and its Transmission Channels." Journal of Development Studies.

Gohou, G. (2012). "Does Foreign Direct Investment Reduce Poverty in Africa and Are There Regional Differences?" World Development 40(1): 75-95.

Gui-Diby, S.L. (2014). "Impact of Foreign Direct Investments on Economic Growth in Africa: Evidence from Three Decades of Panel Data Analyses." Research in Economics, 68(3): 248-256.

Hahn, J. (1998). "On the Role of the Propensity Score in Efficient Semiparametric Estimation of Average Treatment Effects." Econometrica 66: 315-331.

Heckman, J., H. Ichimura, and P. Todd. (1997). "Matching as an Econometric Evaluation Estimator: Evidence from Evaluating a Job Training Programme." Review of Economic Studies 64(4): 605-654.

Heckman, J., H. Ichimura, and P. Todd. (1998). "Matching as an Econometric Evaluations Estimator." Review of Economic Studies 65: 261-294.

Herrmann, R. and U. Crote. (2015). "Large-scale Agro-Industrial Investments and Rural Poverty: Evidence from Sugarcane in Malawi." Journal of African Economies 24 (2015): $1-32$.

Herrmann, R.T. (2017). "Large-Scale Agricultural Investments and Smallholder Welfare: A Comparison of Wage Labor and Outgrower Channels in Tanzania." World Development 90: 294-310.

Henson, S. and T. Reardon. (2005). "Private agri-food standard: Implications for food policy 
and the agri-food system." Food Policy 30:241-253.

Hirano, K. and G.W. Imbens. (2001). "Estimation of Causal Effects using Propensity Score Weighting: An Application to Data on Right Heart Catheterization." Health Services and Outcomes Research Methodology 2: 259-178.

Hirano, K., G.W. Imbens, and G. Ridder. (2003). "Efficient Estimation of Average Treatment Effects Using the Estimated Propensity Score.” Econometrica 71: 1161-1189.

Hjort, J. (2014). "Ethnic Divisions and Production in Firms." Quarterly Journal of Economics 129(4): 1899-1946.

Isgut, A.E. (2001). "What's Different about Exporters? Evidence from Colombian Manufacturing." Journal of Development Studies 37 (5): 57-82.

Kamas, L. and A. Preston. (2012). "The Importance of Being Confident; Gender, Career Choice, and Willingness to Compete." Journal of Economic Behavior and Organization 83: 82-97.

Katz, L. (1986). "Efficiency Wage Theories: A Partial Evaluation" in NBER Macroeconomics Annual 1986, ed. By S. Fischer, Cambridge, MA: MIT Press.

Karlan, D., A.L. Ratan, and J. Zinman. (2014). "Savings by and for the Poor: A Research Review and Agenda." Review of Income and Wealth, 60: 35-78.

Krueger, A.B. and L.H. Summers. (1988). "Efficiency Wages and the Inter-Industry Wage Structure." Econometrica 56(2): 259-293.

Li, X. and X. Liu. (2005). "Foreign Direct Investment and Economic Growth: An Increasingly Endogenous Relationship." World Development 33(3): 393-407.

Maertens, M. and J.F.M. Swinnen. (2009). "Trade, Standards, and Poverty: Evidence from Senegal." World Development 37(1): 161-178.

Maertens, M., L. Colen, J.F.M. Swinnen. (2011). "Globalisation and Poverty in Senegal: A Worst-case Scenario?" European Review of Agricultural Economics 38(1): 31-54.

Mano, Y. and A. Suzuki. (2015). "Industrial Development through Takeovers and Exits: The Case of the Cut Flower Exporters in Ethiopia." Journal of Entrepreneurship and Organization Management 4: 136-144.

Mano, Y., T. Yamano, A. Suzuki, and T. Matsumoto. (2011). "Local and Personal Networks in Employment and the Development of Labor Markets: Evidence from the Cut Flower Industry in Ethiopia." World Development 39: 1760-1770.

Markusen, J.R. and A.J. Venables. (1999). "Foreign Direct Investment as a Catalyst for Industrial Development." European Economic Review 43 (2): 335-356.

Mas, A. and E, Moretti. (2009). "Peers at Work." American Economic Review 99(1): 112-145.

Minten, B., L. Randrianarison, and J.F.M. Swinnen. (2009). "Global Retail Chains and Poor Farmers: Evidence from Madagascar." World Development 37(11): 1728-1741. 
Modigliani, F. and R. Brumberg. (1954). "Utility Analysis and the Consumption Function: an Interpretation of Cross-Section Data." in Kenneth K. Kurihara, ed. Post-Keynesian Economics, New Brunswick, N.J., Rutgers University Press: 388-436.

Modigliani, F. and R. Brumberg. (1979). "Utility Analysis and the Consumption Function: an Attempt at Integration," in Andrew Abel, ed. The collected papers of Franco Modigliani, Vol. 2, Cambridge, Mass, MIT Press: 128-97.

Mullainathan, S. and E. Shafir. (2013). Scarcity: Why Having Too Little Means So Much. New York: Time Books, Henry Holt \& Company LLC.

Munch, J.R. and J.R. Skaksen. (2008). "Human Capital and Wages in Exporting Firms." Journal of International Economics 75: 363-372.

Niederle, M. and L. Vesterlund. (2007). "Do Women Shy Away from Competition? Do Men Compete Too Much?" Quarterly Journal of Economics 122(3): 1067-1101.

Riisgaard, L. (2009). "Global Value Chains, Labor Organization and Private Social Standards: Lessons from East African Cut Flower Industries.” World Development 37(2): 326-340.

Robins, J. and A. Rotnitzky. (1995). "Semiparametric Efficiency in Multivariate Regression Models with Missing Data." Journal of the American Statistical Association 90: 122-129.

Schaefer F. and A. Girum. (2015). "The Case for Industrial Policy and its Application in the Ethiopian Cut Flower Sector.” Working Papers 012, Ethiopian Development Research Institute.

Schank, T., C. Schnabel, and J. Wagner. (2007.) "Do Exporters Really Pay Higher Wages? First Evidence from German linked Employer-Employee Data." Journal of International Economics 72: 52-74.

Stiglitz, J. (1984). “Theories of Wage Rigidities” in Keynes' Economic Legacy: Comtemporary Economic Theories, ed. By J. Butkiewicz, et al. New York: Praeger publishers: 153-206.

Suzuki, A., L.S. Jarvis, and R.J. Sexton. (2011). "Partial Vertical Integration, Risk Shifting, and Product Rejection in the High-Value Export Supply Chain: the Ghana Pineapple Sector." World Development 39: 1611-1623.

Tanaka, T., C. Camerer, and Q. Nguyen. (2010). "Risk and Time Preferences: Linking Experimental Household Survey Data from Vietnam." American Economic Review 100: $557-571$.

Trifkovic, N. (2014). "Governance Strategies and Welfare Effects: Vertical Integration and Contracts in the Catfish Sector in Vietnam.” Journal of Development Studies 50(7): 949961.

Tybout, J.R. and M.D. Westbrook. (1995). "Trade Liberalization and the Dimensions of Efficiency Change in Mexican Manufacturing Industries." Journal of International Economics 39: 53-78. 
Ulrich, A. (2014). "Export-Oriented Horicultural Production in Laikipia, Kenya: Asseessing he Implications for Rural Livelihoods." Sustainability 6: 336-347.

Van den Broeck, G., J. Swinnen, and M. Maertens. (2017). "Global Value Chains, Large-scale Farming, and Poverty: Long-term Effects in Senegal.” Food Policy 66: 97-107.

Wooldridge, J.M. (2007). "Inverse Probability Weighted Estimation for General Missing Data Problems." Journal of Econometrics 141: 1281-1301. 
Table 1: Descriptive Statistics (before matching)

\begin{tabular}{|c|c|c|c|}
\hline & $\begin{array}{c}\text { Production } \\
\text { Worker } \\
(142) \\
\end{array}$ & $\begin{array}{l}\text { Comp } \\
\text { Group } \\
(135) \\
\end{array}$ & $\begin{array}{l}\mathrm{p} \text {-value of } \\
\text { difference }\end{array}$ \\
\hline Age (years) & $\begin{array}{c}25.1 \\
(7.08)\end{array}$ & $\begin{array}{c}27.1 \\
(8.18)\end{array}$ & $0.03 * *$ \\
\hline Female $(=1)$ & $\begin{array}{l}0.796 \\
(0.40)\end{array}$ & $\begin{array}{l}0.726 \\
(0.45)\end{array}$ & 0.17 \\
\hline Years of schooling (years) & $\begin{array}{c}5.96 \\
(3.65)\end{array}$ & $\begin{array}{c}6.2 \\
(3.77)\end{array}$ & 0.59 \\
\hline Math Score & $\begin{array}{c}5.96 \\
(5.08)\end{array}$ & $\begin{array}{c}7.87 \\
(6.76)\end{array}$ & $0.01 * * *$ \\
\hline Mothers Edu (years) & $\begin{array}{c}1.34 \\
(2.73)\end{array}$ & $\begin{array}{c}1.46 \\
(3.03)\end{array}$ & 0.72 \\
\hline Father Edu (years) & $\begin{array}{c}2.45 \\
(3.96)\end{array}$ & $\begin{array}{c}2.75 \\
(4.05)\end{array}$ & 0.54 \\
\hline Parents farmer $(=1)$ & $\begin{array}{l}0.725 \\
(0.45)\end{array}$ & $\begin{array}{c}0.60 \\
(0.49)\end{array}$ & $0.03 * *$ \\
\hline Parents keep livestock $(=1)$ & $\begin{array}{l}0.648 \\
(0.48)\end{array}$ & $\begin{array}{l}0.578 \\
(0.50)\end{array}$ & 0.23 \\
\hline Number of HH members (including self) & $\begin{array}{c}3.18 \\
(1.90)\end{array}$ & $\begin{array}{c}3.21 \\
(1.94)\end{array}$ & 0.89 \\
\hline Number of dependents in $\mathrm{HH}$ & $\begin{array}{c}1.11 \\
(1.33)\end{array}$ & $\begin{array}{c}1.28 \\
(1.50)\end{array}$ & 0.30 \\
\hline Years worked at current place (years) & $\begin{array}{c}3.59 \\
(2.44)\end{array}$ & $\begin{array}{c}5.31 \\
(6.96)\end{array}$ & $0.01 * * *$ \\
\hline Born in the current village $(=1)$ & $\begin{array}{c}0.42 \\
(0.49)\end{array}$ & $\begin{array}{c}0.36 \\
(0.48)\end{array}$ & 0.37 \\
\hline Years living in the village (years) & $\begin{array}{c}16.3 \\
(11.2)\end{array}$ & $\begin{array}{c}16.3 \\
(12.3)\end{array}$ & 0.99 \\
\hline Risk Averse (1-9; 9 most risk averse) & $\begin{array}{c}5.35 \\
(2.34)\end{array}$ & $\begin{array}{c}5.30 \\
(2.34)\end{array}$ & 0.86 \\
\hline Competitive ( $1-3 ; 3$ most competitive) & $\begin{array}{c}1.94 \\
(0.75)\end{array}$ & $\begin{array}{c}1.73 \\
(0.76)\end{array}$ & $0.03 * *$ \\
\hline Absolute overconfidence & $\begin{array}{c}9.33 \\
(14.77)\end{array}$ & $\begin{array}{c}6.97 \\
(13.86)\end{array}$ & 0.17 \\
\hline Relative overconfidence & $\begin{array}{c}0.07 \\
(1.53)\end{array}$ & $\begin{array}{c}0.45 \\
(1.46)\end{array}$ & $0.04 * *$ \\
\hline
\end{tabular}

Note) Standard deviations are in parentheses. $* * p<0.05$; *** $p<0.01$. 
Table 2: Average Financial Performance (before matching)

\begin{tabular}{|c|c|c|c|}
\hline & $\begin{array}{c}\text { Production } \\
\text { Worker } \\
(142)\end{array}$ & $\begin{array}{l}\text { Comp } \\
\text { Group } \\
\text { (135) }\end{array}$ & $\begin{array}{l}\mathrm{p} \text {-value of } \\
\text { difference }\end{array}$ \\
\hline Monthly income of respondent (Birr) & $\begin{array}{c}735.2 \\
(168.6)\end{array}$ & $\begin{array}{c}726.9 \\
(583.3)\end{array}$ & 0.87 \\
\hline Wage per hour of respondent (Birr) & $\begin{array}{c}3.70 \\
(0.98)\end{array}$ & $\begin{array}{c}4.32 \\
(4.58)\end{array}$ & 0.12 \\
\hline Hours worked per month & $\begin{array}{l}201.8 \\
(20.9)\end{array}$ & $\begin{array}{l}196.5 \\
(86.6)\end{array}$ & 0.48 \\
\hline$=1$ if save regularly or unregularly & $\begin{array}{c}0.64 \\
(0.48)\end{array}$ & $\begin{array}{c}0.46 \\
(0.50)\end{array}$ & $0.00 * * *$ \\
\hline Saving rate (saving amount / income) & $\begin{array}{c}0.13 \\
(0.15)\end{array}$ & $\begin{array}{c}0.10 \\
(0.16)\end{array}$ & 0.13 \\
\hline Monthly saving if saved (Birr) & $\begin{array}{c}95.56 \\
(117.4)\end{array}$ & $\begin{array}{l}131.48 \\
(252.1\end{array}$ & 0.13 \\
\hline $\begin{array}{l}=1 \text { if send remittance regularly or } \\
\text { unregularly }\end{array}$ & $\begin{array}{c}0.30 \\
(0.46)\end{array}$ & $\begin{array}{c}0.30 \\
(0.46)\end{array}$ & 0.94 \\
\hline Monthly remittance sent if remit(Birr) & $\begin{array}{c}24.1 \\
(58.7)\end{array}$ & $\begin{array}{c}35.6 \\
(71.9)\end{array}$ & 0.14 \\
\hline Monthly HH income & $\begin{array}{l}1221.1 \\
(775.3)\end{array}$ & $\begin{array}{l}1388.2 \\
(922.4)\end{array}$ & 0.10 \\
\hline Monthly HH income per capita & $\begin{array}{c}481.2 \\
(301.9)\end{array}$ & $\begin{array}{c}550.2 \\
(409.2)\end{array}$ & 0.11 \\
\hline$\%$ of contribution to $\mathrm{HH}$ income & $\begin{array}{c}54.6 \\
(36.8)\end{array}$ & $\begin{array}{c}55.5 \\
(37.1)\end{array}$ & 0.84 \\
\hline$\%$ of food purchase in $\mathrm{HH}$ expenditure & $\begin{array}{c}57.4 \\
(50.3)\end{array}$ & $\begin{array}{c}58.2 \\
(77.2)\end{array}$ & 0.93 \\
\hline
\end{tabular}

Note) Standard deviations are in parentheses. . ${ }^{* * *} p<0.01$ 
Table 3: Probit estimation for matching (Marginal Effect)

\begin{tabular}{lc}
\hline & $=1$ if in Cut Flower \\
\hline \hline Age & $-0.013^{* *}$ \\
=1 if female & $(0.006)$ \\
& $0.133^{*}$ \\
Years of schooling & $(0.077)$ \\
& 0.005 \\
Math score & $(0.012)$ \\
& $-0.024^{* * *}$ \\
1 if parents are farmers & $(0.007)$ \\
& $0.189^{* * *}$ \\
$=1$ if born in this village & $(0.072)$ \\
& $0.118^{*}$ \\
Risk averse & $(0.073)$ \\
& 0.005 \\
Competitive & $(0.014)$ \\
& $0.126^{* * *}$ \\
Absolute overconfidence & $(0.045)$ \\
& 0.002 \\
Relative overconfidence & $(0.002)$ \\
& $-0.072^{* * *}$ \\
Pseudo $R^{2}$ & $(0.022)$ \\
LR chi & 0.115 \\
$N$ & $41.79^{* * *}$ \\
& 265 \\
\hline
\end{tabular}

Note) Robust Z-stats are in parentheses. . ${ }^{*} p<0.1 ; * * p<0.05 ; * * * p<0.01$

Table 4: Matching Methods and Balancing

\begin{tabular}{lcccc}
\hline & $\begin{array}{c}\text { \# significant } \\
\text { variables }\end{array}$ & Pseudo R2 & $\begin{array}{c}\text { P-value LR } \\
\text { test }\end{array}$ & Mean Bias \\
\hline \hline Before matching & 4 & 0.115 & 0.000 & 19.9 \\
Nearest Neighbor & 0 & 0.018 & 0.749 & 9.3 \\
Caliper (radius=0.01) & 0 & 0.003 & 1.000 & 4.3 \\
Kernel & 0 & 0.009 & 0.973 & 6.9 \\
\hline
\end{tabular}


Table 5: Effects of Cut Flower on Financial Performances

\begin{tabular}{|c|c|c|}
\hline & \multicolumn{2}{|c|}{ PSM } \\
\hline & $\begin{array}{c}\text { Caliper } \\
(1)\end{array}$ & $\begin{array}{c}\text { Kernel } \\
(2)\end{array}$ \\
\hline \multicolumn{3}{|c|}{ A. Before the current job } \\
\hline \multirow[t]{2}{*}{$\ln (\text { worker's yearly income }+1)^{*}$} & -0.62 & $-1.39 * *$ \\
\hline & $(0.61)$ & $(0.59)$ \\
\hline \multirow[t]{2}{*}{$\ln ($ worker's yearly income) } & 0.22 & 0.18 \\
\hline & $(0.20)$ & $(0.16)$ \\
\hline \multirow[t]{2}{*}{$=1$ if save } & -0.09 & $-0.10^{*}$ \\
\hline & $(0.08)$ & $(0.06)$ \\
\hline \multirow[t]{2}{*}{ Saving rate } & 0.003 & -0.03 \\
\hline & $(0.05)$ & $(0.04)$ \\
\hline \multirow[t]{2}{*}{$=1$ if send money } & 0.01 & 0.03 \\
\hline & $(0.05)$ & $(0.05)$ \\
\hline \multirow[t]{2}{*}{$\ln (\mathrm{HH}$ monthly income per capita) } & 0.16 & 0.14 \\
\hline & $(0.22)$ & $(0.13)$ \\
\hline \multirow[t]{2}{*}{$\%$ contribution to $\mathrm{HH}$} & -3.74 & -6.26 \\
\hline & $(6.92)$ & $(6.39)$ \\
\hline \multirow{3}{*}{$\ln ($ my yearly income $)$} & ntly & \\
\hline & $0.31 * *$ & $0.29 * * *$ \\
\hline & $(0.15)$ & $(0.11)$ \\
\hline \multirow[t]{2}{*}{$\ln ($ my hourly wage) } & 0.14 & 0.17 \\
\hline & $(0.15)$ & $(0.12)$ \\
\hline \multirow[t]{2}{*}{$=1$ if save } & $0.19 * *$ & $0.18 *$ \\
\hline & $(0.08)$ & $(0.09)$ \\
\hline \multirow[t]{2}{*}{ Saving rate } & $0.06^{* *}$ & $0.04 *$ \\
\hline & $(0.03)$ & $(0.02)$ \\
\hline \multirow[t]{2}{*}{$=1$ if send money } & -0.02 & 0.03 \\
\hline & $(0.09)$ & $(0.08)$ \\
\hline \multirow[t]{2}{*}{$\ln (\mathrm{HH}$ monthly income per capita) } & -0.09 & $-0.14^{*}$ \\
\hline & $(0.10)$ & $(0.08)$ \\
\hline \multirow[t]{2}{*}{$\%$ contribution to $\mathrm{HH}$} & -2.14 & 1.65 \\
\hline & $(5.45)$ & $(6.68)$ \\
\hline
\end{tabular}

Note) Bootstrapped z-statistics are in parentheses. . * $p<0.1 ; * * p<0.05 ; * * * p<0.01$.

*: 1 is added to the yearly income in order not to lose the observations with no income. 
Table 6: Effects of Cut Flower on Job Satisfaction

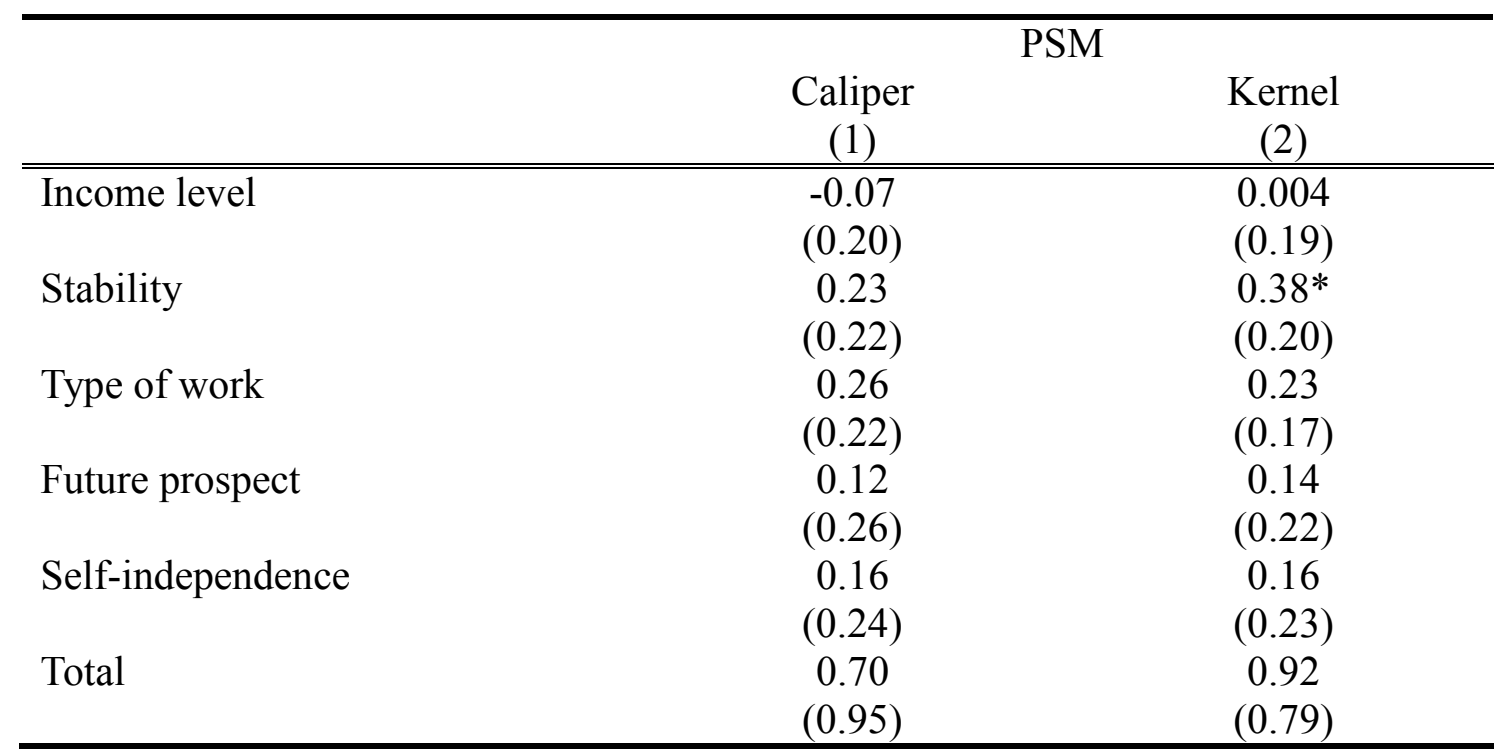

Note) Bootstrapped z-statistics are in parentheses. . ${ }^{*} p<0.1$. 
Table 7: Effects of Cut Flower on Income and Wage (Inverse P-score weighting regression, Treatment effect on the treated, Trimmed sample)

\begin{tabular}{|c|c|c|c|c|c|}
\hline \multirow{3}{*}{ Worker-level Characteristics } & \multirow{2}{*}{\multicolumn{2}{|c|}{$\begin{array}{l}\ln \text { (worker's yearly income) } \\
\text { (1) }\end{array}$}} & \multicolumn{3}{|c|}{$\ln ($ worker's hourly wage) } \\
\hline & & & (3) & (4) & $(5)$ \\
\hline & & & & & \\
\hline$=1$ if in Cut Flower & $\begin{array}{l}0.443 * * * \\
(5.28)\end{array}$ & $\begin{array}{l}0.260 * * * \\
(3.65)\end{array}$ & $\begin{array}{l}0.363 * * * \\
(4.41)\end{array}$ & $\begin{array}{l}0.202 * * * \\
(3.07)\end{array}$ & \\
\hline Age & $-0.017 * *$ & $-0.014^{*}$ & -0.012 & -0.009 & 0.001 \\
\hline & $(2.00)$ & $(1.79)$ & $(1.62)$ & (1.38) & $(0.31)$ \\
\hline$=1$ if female & -0.018 & -0.063 & -0.028 & -0.068 & $-0.106^{* * *}$ \\
\hline & $(0.20)$ & $(0.71)$ & $(0.33)$ & $(0.80)$ & $(2.65)$ \\
\hline Years of schooling & -0.008 & -0.010 & -0.010 & -0.011 & -0.001 \\
\hline & $(0.52)$ & $(0.69)$ & $(0.66)$ & $(0.83)$ & $(0.19)$ \\
\hline Years worked here & $\begin{array}{l}0.062 * * * \\
(5.43)\end{array}$ & $\begin{array}{l}0.065 * * * \\
(5.64)\end{array}$ & $\begin{array}{l}0.055^{* * * *} \\
(5.03)\end{array}$ & $\begin{array}{l}0.058 * * * \\
(5.05)\end{array}$ & $\begin{array}{c}0.042^{* * * *} \\
(4.59)\end{array}$ \\
\hline Math score & $\begin{array}{c}0.021 * * \\
(2.22)\end{array}$ & $\begin{array}{c}0.017 * \\
(1.88)\end{array}$ & $\begin{array}{c}0.022 * * \\
(2.50)\end{array}$ & $\begin{array}{c}0.019 * * \\
(2.19)\end{array}$ & $\begin{array}{r}-0.000 \\
(0.00)\end{array}$ \\
\hline \# HH members & $\begin{array}{l}-0.038^{*} \\
(1.77)\end{array}$ & $\begin{array}{c}-0.041 * * \\
(2.00)\end{array}$ & $\begin{array}{c}-0.036^{*} \\
(1.88)\end{array}$ & $\begin{array}{c}-0.039 * * \\
(2.11)\end{array}$ & $\begin{array}{l}-0.005 \\
(0.53)\end{array}$ \\
\hline Risk averse & $\begin{array}{l}0.030 \\
(1.54)\end{array}$ & $\begin{array}{c}0.032 * \\
(1.73)\end{array}$ & $\begin{array}{l}0.028 \\
(1.47)\end{array}$ & $\begin{array}{l}0.029 \\
(1.63)\end{array}$ & $\begin{array}{l}0.004 \\
(0.67)\end{array}$ \\
\hline Competitive & $\begin{array}{l}-0.007 \\
(0.11)\end{array}$ & $\begin{array}{l}0.025 \\
(0.43)\end{array}$ & $\begin{array}{l}-0.012 \\
(0.22)\end{array}$ & $\begin{array}{l}0.016 \\
(0.29)\end{array}$ & $\begin{array}{l}-0.019 \\
(1.11)\end{array}$ \\
\hline Absolute overconfidence & $\begin{array}{l}0.003 \\
(1.11)\end{array}$ & $\begin{array}{l}0.004 \\
(1.65)\end{array}$ & $\begin{array}{l}0.004^{*} \\
(1.74)\end{array}$ & $\begin{array}{c}0.005^{* *} \\
(2.35)\end{array}$ & $\begin{array}{l}0.001 \\
(1.30)\end{array}$ \\
\hline Relative overconfidence & $\begin{array}{l}-0.012 \\
(0.40)\end{array}$ & $\begin{array}{l}-0.008 \\
(0.28)\end{array}$ & $\begin{array}{c}-0.008 \\
(0.27)\end{array}$ & $\begin{array}{r}-0.004 \\
(0.15)\end{array}$ & $\begin{array}{l}-0.010 \\
(1.28)\end{array}$ \\
\hline Hours worked per month & $\begin{array}{l}0.001 \\
(0.80)\end{array}$ & $\begin{array}{l}0.001 \\
(0.63)\end{array}$ & $\begin{array}{l}-0.005 * * * \\
(4.72)\end{array}$ & $\begin{array}{l}-0.005^{* * *} \\
(5.05)\end{array}$ & $\begin{array}{l}-0.003 \\
(1.39)\end{array}$ \\
\hline Frequency of payment & $\begin{array}{c}0.308^{* *} \\
(2.06)\end{array}$ & $\begin{array}{l}0.447 * * * \\
(3.64)\end{array}$ & $\begin{array}{c}0.308^{* * *} \\
(2.13)\end{array}$ & $\begin{array}{c}0.429 * * * \\
(3.50)\end{array}$ & $\begin{array}{l}0.042 \\
(0.55)\end{array}$ \\
\hline$=1$ if hired & & $\begin{array}{l}0.576^{* * *} \\
(3.29)\end{array}$ & & $\begin{array}{l}0.504 * * * \\
(2.99)\end{array}$ & \\
\hline $\begin{array}{l}\text { CF firm's turnover rate } \\
2010\end{array}$ & & & & & $\begin{array}{c}0.033 * * * \\
(3.69)\end{array}$ \\
\hline Wereda-level Characteristics & & & & & \\
\hline \# CF workers & $\begin{array}{l}-0.000 \\
(0.82)\end{array}$ & $\begin{array}{l}-0.000 \\
(0.75)\end{array}$ & $\begin{array}{l}-0.000 \\
(0.27)\end{array}$ & $\begin{array}{l}-0.000 \\
(0.22)\end{array}$ & $\begin{array}{c}-0.000 * * * \\
(4.09)\end{array}$ \\
\hline \# working population & $\begin{array}{r}-0.000 \\
(0.59)\end{array}$ & $\begin{array}{r}-0.000 \\
(1.58)\end{array}$ & $\begin{array}{c}-0.000 \\
(0.75)\end{array}$ & $\begin{array}{r}-0.000 \\
(1.63)\end{array}$ & $\begin{array}{c}0.000^{* *} \\
(2.18)\end{array}$ \\
\hline Constant & $\begin{array}{c}8.440 * * * \\
(19.44)\end{array}$ & $\begin{array}{c}7.999 * * * \\
(17.40)\end{array}$ & $\begin{array}{c}1.976^{* * *} \\
(4.87) \\
\end{array}$ & $\begin{array}{c}1.590 * * * \\
(3.65) \\
\end{array}$ & $\begin{array}{c}1.719 * * * \\
(4.11) \\
\end{array}$ \\
\hline$R^{2}$ & 0.32 & 0.39 & 0.41 & 0.47 & 0.74 \\
\hline$N$ & 244 & 244 & 244 & 244 & 115 \\
\hline
\end{tabular}

Note) All includes zone fixed effects. Weights are from the propensity score to work in the CF sector. Robust tstatistics in parentheses. Column (5) is for workers in the CF sector only. ${ }^{*} p<0.1 ; * * p<0.05$; ${ }^{* * *} p<0.01$ 
Table 8-1: Effects of Cut Flower on Saving Behavior (Inverse P-score weighting regression, Treatment effect on the treated, Trimmed sample)

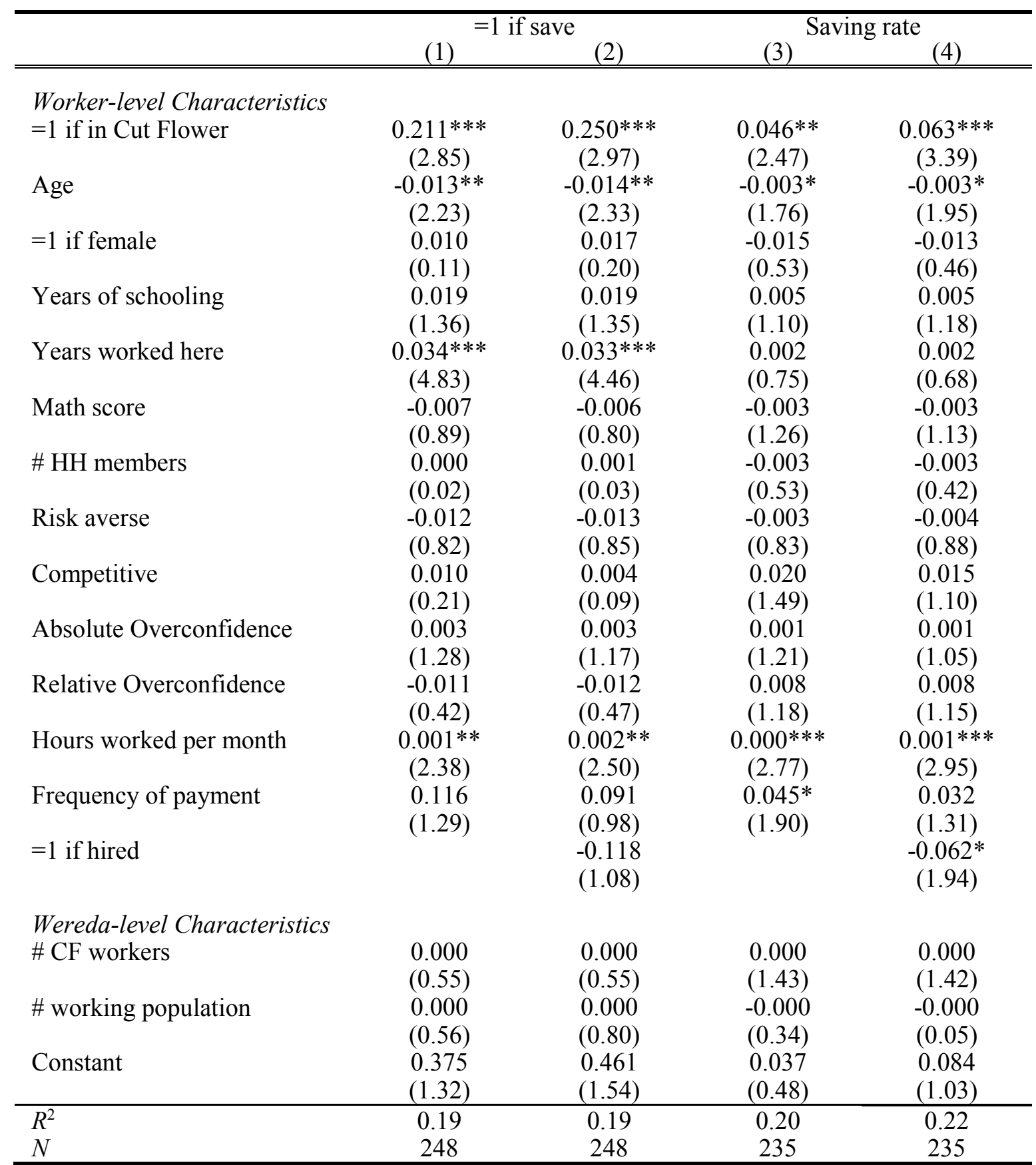

Note) All includes zone fixed effects. Weights are from the propensity score to work in the CF sector. Robust tstatistics in parentheses. $* p<0.1 ; * * p<0.05 ; * * * p<0.01$ 
Table 8-2: Effects of Cut Flower on Saving Behavior Using Sub-Samples (Inverse Pscore weighting regression, Treatment effect on the treated, Trimmed sample)

\begin{tabular}{|c|c|c|c|c|}
\hline & \multicolumn{2}{|c|}{ Lower income } & \multicolumn{2}{|c|}{ Higher income } \\
\hline & $\begin{array}{c}=1 \text { if save } \\
\text { (1) }\end{array}$ & $\begin{array}{c}\text { Saving rate } \\
\text { (2) }\end{array}$ & $\begin{array}{c}=1 \text { if save } \\
(3)\end{array}$ & $\begin{array}{c}\text { Saving rate } \\
\text { (4) }\end{array}$ \\
\hline Worker-level Characteristics & & & & \\
\hline$=1$ if in Cut Flower & $\begin{array}{c}0.418 * * * \\
\quad(3.74)\end{array}$ & $\begin{array}{c}0.090 * * * \\
(3.57)\end{array}$ & $\begin{array}{c}-0.134 \\
(0.79)\end{array}$ & $\begin{array}{c}-0.001 \\
(0.02)\end{array}$ \\
\hline Age & -0.004 & -0.002 & $-0.027 * * *$ & $-0.005 * *$ \\
\hline & $\begin{array}{c}(0.56) \\
-0.146\end{array}$ & $(0.99)$ & (3.24) & $(2.27)$ \\
\hline$=1$ if female & $\begin{array}{c}-0.146 \\
(1.26)\end{array}$ & $\begin{array}{c}-0.005 \\
(0.14)\end{array}$ & $\begin{array}{l}0.127 \\
(1.09)\end{array}$ & $\begin{array}{c}-0.035 \\
(0.81)\end{array}$ \\
\hline Years of schooling & $\begin{array}{l}0.026 \\
(1.39)\end{array}$ & $\begin{array}{l}0.008 \\
(1.41)\end{array}$ & $\begin{array}{l}0.002 \\
(0.10)\end{array}$ & $\begin{array}{c}-0.000 \\
(0.01)\end{array}$ \\
\hline Years worked here & $\begin{array}{c}0.035 * * * \\
(4.10)\end{array}$ & $\begin{array}{l}0.006 \\
(1.36)\end{array}$ & $\begin{array}{l}0.026 \\
(1.31)\end{array}$ & $\begin{array}{l}0.001 \\
(0.13)\end{array}$ \\
\hline Math score & $\begin{array}{l}0.001 \\
(0.09)\end{array}$ & $\begin{array}{c}-0.002 \\
(0.69)\end{array}$ & $\begin{array}{c}-0.016 \\
(1.24)\end{array}$ & $\begin{array}{c}-0.004 \\
(0.82)\end{array}$ \\
\hline \# HH members & $\begin{array}{c}-0.007 \\
(0.25)\end{array}$ & $\begin{array}{l}0.001 \\
(0.08)\end{array}$ & $\begin{array}{l}0.016 \\
(0.46)\end{array}$ & $\begin{array}{c}-0.002 \\
(0.19)\end{array}$ \\
\hline Risk averse & $\begin{array}{c}-0.008 \\
(0.43)\end{array}$ & $\begin{array}{c}-0.002 \\
(0.30)\end{array}$ & $\begin{array}{c}-0.024 \\
(1.11)\end{array}$ & $\begin{array}{c}-0.007 \\
(1.22)\end{array}$ \\
\hline Competitive & $\begin{array}{l}0.015 \\
(0.25)\end{array}$ & $\begin{array}{l}0.016 \\
(0.95)\end{array}$ & $\begin{array}{l}0.041 \\
(0.50)\end{array}$ & $\begin{array}{l}0.015 \\
(0.65)\end{array}$ \\
\hline Absolute Overconfidence & $\begin{array}{l}0.005 \\
(1.60)\end{array}$ & $\begin{array}{l}0.001 \\
(1.43)\end{array}$ & $\begin{array}{l}0.001 \\
(0.38)\end{array}$ & $\begin{array}{l}0.001 \\
(0.51)\end{array}$ \\
\hline Relative Overconfidence & $\begin{array}{c}0.008 \\
(0.23)\end{array}$ & $\begin{array}{l}0.004 \\
(0.48)\end{array}$ & $\begin{array}{c}-0.047 \\
(1.17)\end{array}$ & $\begin{array}{l}0.008 \\
(0.77)\end{array}$ \\
\hline Frequency of payment & $\begin{array}{c}0.002 * * * \\
(4.01)\end{array}$ & $\begin{array}{c}0.001 * * * \\
(2.75)\end{array}$ & $\begin{array}{l}0.001 \\
(0.45)\end{array}$ & $\begin{array}{l}0.000 \\
(0.38)\end{array}$ \\
\hline Hours worked per month & $\begin{array}{c}-0.008 \\
(0.09)\end{array}$ & $\begin{array}{l}0.008 \\
(0.25)\end{array}$ & $\begin{array}{l}0.118 \\
(0.57)\end{array}$ & $\begin{array}{l}0.015 \\
(0.30)\end{array}$ \\
\hline$=1$ if hired & $\begin{array}{c}-0.343^{* * * *} \\
(2.82)\end{array}$ & $\begin{array}{c}-0.123^{* * * *} \\
(2.88)\end{array}$ & $\begin{array}{l}0.210 \\
(1.04)\end{array}$ & $\begin{array}{c}-0.027 \\
(0.51)\end{array}$ \\
\hline $\begin{array}{l}\text { Wereda-level Characteristics } \\
\text { \# CF workers }\end{array}$ & $\begin{array}{l}0.000 * * \\
(2.17)\end{array}$ & $\begin{array}{l}0.000 \\
(1.52)\end{array}$ & $\begin{array}{l}0.000 \\
(0.02)\end{array}$ & $\begin{array}{l}0.000 \\
(1.12)\end{array}$ \\
\hline \# working population & $\begin{array}{c}0.000^{*} \\
(1.86)\end{array}$ & $\begin{array}{l}0.000 \\
(1.26)\end{array}$ & $\begin{array}{c}-0.000 \\
(0.73)\end{array}$ & $\begin{array}{c}-0.000 \\
(1.17)\end{array}$ \\
\hline Constant & $\begin{array}{l}0.289 \\
(0.83)\end{array}$ & $\begin{array}{l}0.031 \\
(0.31)\end{array}$ & $\begin{array}{l}0.570 \\
(1.07)\end{array}$ & $\begin{array}{l}0.193 \\
(1.32)\end{array}$ \\
\hline $\begin{array}{l}R^{2} \\
N\end{array}$ & $\begin{array}{l}0.38 \\
143\end{array}$ & $\begin{array}{l}0.36 \\
130\end{array}$ & $\begin{array}{l}0.23 \\
105\end{array}$ & $\begin{array}{l}0.21 \\
105\end{array}$ \\
\hline
\end{tabular}

Note) All includes zone fixed effects. Weights are from the propensity score to work in the CF sector. Robust tstatistics in parentheses. $* p<0.1 ; * * p<0.05 ; * * * p<0.01$ 
Table 9: Effects of Cut Flower on Job Satisfaction (Inverse P-score weighting regression, Treatment effect on the treated, Trimmed sample)

\begin{tabular}{|c|c|c|c|c|c|c|}
\hline & $\begin{array}{c}\text { Income } \\
(1) \\
\end{array}$ & $\begin{array}{c}\text { Stability } \\
(2) \\
\end{array}$ & $\begin{array}{c}\text { Type of } \\
\text { work } \\
(3) \\
\end{array}$ & $\begin{array}{c}\text { Future } \\
\text { prospect } \\
(4) \\
\end{array}$ & $\begin{array}{c}\text { Self- } \\
\text { independe } \\
\text { nce } \\
(5) \\
\end{array}$ & $\begin{array}{c}\text { Total } \\
(6) \\
\end{array}$ \\
\hline \multicolumn{7}{|c|}{ Worker-level Characteristics } \\
\hline$=1$ if in Cut Flower & $\begin{array}{c}0.385^{* *} \\
(2.15)\end{array}$ & $\begin{array}{c}0.748 * * * \\
(4.19)\end{array}$ & $\begin{array}{l}0.233 \\
(1.14)\end{array}$ & $\begin{array}{c}0.481 * * \\
(2.17)\end{array}$ & $\begin{array}{l}0.232 \\
(1.35)\end{array}$ & $\begin{array}{c}2.079 * * * \\
(2.95)\end{array}$ \\
\hline Age & $\begin{array}{l}0.001 \\
(0.10)\end{array}$ & $\begin{array}{r}-0.003 \\
(0.27)\end{array}$ & $\begin{array}{l}0.003 \\
(0.20)\end{array}$ & $\begin{array}{l}0.015 \\
(0.96)\end{array}$ & $\begin{array}{l}-0.001 \\
(0.07)\end{array}$ & $\begin{array}{l}0.015 \\
(0.27)\end{array}$ \\
\hline$=1$ if female & $\begin{array}{l}0.123 \\
(0.72)\end{array}$ & $\begin{array}{c}0.148 \\
(0.86)\end{array}$ & $\begin{array}{l}0.138 \\
(0.58)\end{array}$ & $\begin{array}{r}-0.111 \\
(0.54)\end{array}$ & $\begin{array}{l}0.013 \\
(0.07)\end{array}$ & $\begin{array}{l}0.312 \\
(0.43)\end{array}$ \\
\hline Years of schooling & $\begin{array}{l}0.004 \\
(0.13)\end{array}$ & $\begin{array}{c}0.027 \\
(0.94)\end{array}$ & $\begin{array}{l}0.021 \\
(0.63)\end{array}$ & $\begin{array}{l}0.002 \\
(0.06)\end{array}$ & $\begin{array}{r}-0.021 \\
(0.63)\end{array}$ & $\begin{array}{l}0.033 \\
(0.27)\end{array}$ \\
\hline Years worked here & $\begin{array}{l}0.004 \\
(0.22)\end{array}$ & $\begin{array}{l}0.020 \\
(1.10)\end{array}$ & $\begin{array}{l}-0.014 \\
(0.52)\end{array}$ & $\begin{array}{l}0.005 \\
(0.24)\end{array}$ & $\begin{array}{c}-0.049 * \\
(1.65)\end{array}$ & $\begin{array}{l}-0.034 \\
(0.38)\end{array}$ \\
\hline Math score & $\begin{array}{l}-0.006 \\
(0.34)\end{array}$ & $\begin{array}{l}-0.007 \\
(0.39)\end{array}$ & $\begin{array}{l}-0.009 \\
(0.41)\end{array}$ & $\begin{array}{l}0.004 \\
(0.19)\end{array}$ & $\begin{array}{l}0.009 \\
(0.44)\end{array}$ & $\begin{array}{l}-0.009 \\
(0.11)\end{array}$ \\
\hline \# HH members & $\begin{array}{l}0.026 \\
(0.63)\end{array}$ & $\begin{array}{l}0.040 \\
(1.00)\end{array}$ & $\begin{array}{c}-0.028 \\
(0.57)\end{array}$ & $\begin{array}{l}-0.080 \\
(1.62)\end{array}$ & $\begin{array}{l}-0.033 \\
(0.76)\end{array}$ & $\begin{array}{l}-0.075 \\
(0.43)\end{array}$ \\
\hline Risk averse & $\begin{array}{l}0.011 \\
(0.32)\end{array}$ & $\begin{array}{l}0.029 \\
(0.84)\end{array}$ & $\begin{array}{l}0.021 \\
(0.49)\end{array}$ & $\begin{array}{l}0.016 \\
(0.37)\end{array}$ & $\begin{array}{l}-0.009 \\
(0.24)\end{array}$ & $\begin{array}{l}0.067 \\
(0.50)\end{array}$ \\
\hline Competitive & $\begin{array}{l}0.148 \\
(1.52)\end{array}$ & $\begin{array}{l}0.117 \\
(1.15)\end{array}$ & $\begin{array}{l}0.097 \\
(0.81)\end{array}$ & $\begin{array}{l}0.135 \\
(1.12)\end{array}$ & $\begin{array}{l}0.010 \\
(0.09)\end{array}$ & $\begin{array}{l}0.507 \\
(1.21)\end{array}$ \\
\hline Absolute & 0.001 & -0.002 & 0.002 & 0.006 & -0.000 & 0.007 \\
\hline Overconfidence & $(0.14)$ & $(0.25)$ & $(0.34)$ & $(0.81)$ & $(0.03)$ & $(0.29)$ \\
\hline Relative & -0.026 & -0.031 & -0.045 & 0.051 & 0.024 & -0.027 \\
\hline Overconfidence & $(0.45)$ & $(0.56)$ & $(0.66)$ & $(0.79)$ & $(0.43)$ & $(0.12)$ \\
\hline $\begin{array}{l}\text { Hours worked per } \\
\text { month }\end{array}$ & $\begin{array}{l}0.005 * * * \\
(4.01)\end{array}$ & $\begin{array}{c}0.003 * * \\
(2.39)\end{array}$ & $\begin{array}{l}0.002 \\
(1.48)\end{array}$ & $\begin{array}{l}0.003 * \\
(1.81)\end{array}$ & $\begin{array}{l}0.003 * \\
(1.81)\end{array}$ & $\begin{array}{l}0.018 * * * \\
\quad(2.94)\end{array}$ \\
\hline $\begin{array}{l}\text { Frequency of } \\
\text { payment }\end{array}$ & $\begin{array}{l}0.231 \\
(1.29)\end{array}$ & $\begin{array}{l}0.050 \\
(0.26)\end{array}$ & $\begin{array}{r}-0.382 \\
(1.50)\end{array}$ & $\begin{array}{r}-0.020 \\
(0.09)\end{array}$ & $\begin{array}{l}-0.128 \\
(0.59)\end{array}$ & $\begin{array}{r}-0.249 \\
(0.31)\end{array}$ \\
\hline$=1$ if hired & $\begin{array}{c}-0.623 * * * \\
(2.74)\end{array}$ & $\begin{array}{c}-0.680^{* * * *} \\
(3.22)\end{array}$ & $\begin{array}{c}-0.615^{* *} \\
(2.12)\end{array}$ & $\begin{array}{c}-0.619^{* *} \\
(1.98)\end{array}$ & $\begin{array}{l}-0.286 \\
(0.92)\end{array}$ & $\begin{array}{c}-2.823 * * \\
(2.60)\end{array}$ \\
\hline \multicolumn{7}{|c|}{ Wereda-level Characteristics } \\
\hline \# CF workers & $\begin{array}{c}-0.000 \\
(1.25)\end{array}$ & $\begin{array}{l}-0.000 \\
(0.96)\end{array}$ & $\begin{array}{l}0.000 \\
(0.55)\end{array}$ & $\begin{array}{c}-0.000 * * \\
(2.50)\end{array}$ & $\begin{array}{c}-0.000 * * * \\
(4.53)\end{array}$ & $\begin{array}{c}-0.000 * * \\
(2.23)\end{array}$ \\
\hline \# working pop. & $\begin{array}{l}-0.000 \\
(0.69)\end{array}$ & $\begin{array}{l}-0.000 \\
(0.82)\end{array}$ & $\begin{array}{l}0.000 \\
(1.37)\end{array}$ & $\begin{array}{l}0.000 \\
(1.62)\end{array}$ & $\begin{array}{c}0.000^{*} \\
(1.78)\end{array}$ & $\begin{array}{l}0.000 \\
(0.94)\end{array}$ \\
\hline Constant & $\begin{array}{r}1.040 \\
(1.43) \\
\end{array}$ & $\begin{array}{l}1.267^{*} \\
(1.84)\end{array}$ & $\begin{array}{c}2.970 * * * \\
(3.80)\end{array}$ & $\begin{array}{l}1.614 \\
(1.62) \\
\end{array}$ & $\begin{array}{c}2.757 * * * \\
(2.92)\end{array}$ & $\begin{array}{c}9.648 * * * \\
(2.97)\end{array}$ \\
\hline$R^{2}$ & 0.38 & 0.36 & 0.15 & 0.25 & 0.29 & 0.33 \\
\hline$N$ & 248 & 248 & 248 & 248 & 248 & 248 \\
\hline
\end{tabular}


Table 10: Heterogeneous Effects of Cut Flower on Income and Saving rate (Inverse Pscore weighting regression, Treatment effect on the treated, Trimmed sample)

\begin{tabular}{|c|c|c|c|c|}
\hline & $\begin{array}{c}\ln (\text { my } \\
\text { yearly } \\
\text { income }) \\
(1) \\
\end{array}$ & $\begin{array}{c}\ln (\mathrm{my} \\
\text { hourly } \\
\text { wage) } \\
(2) \\
\end{array}$ & $\begin{array}{c}=1 \text { if save } \\
(3) \\
\end{array}$ & $\begin{array}{c}\text { Saving rate } \\
\text { (4) } \\
\end{array}$ \\
\hline \multicolumn{5}{|l|}{ CF dummy $x$ : } \\
\hline Female & $\begin{array}{l}0.076 \\
(0.44)\end{array}$ & $\begin{array}{l}0.067 \\
(0.41)\end{array}$ & $\begin{array}{l}0.094 \\
(0.57)\end{array}$ & $\begin{array}{l}0.029 \\
(0.58)\end{array}$ \\
\hline Age & $\begin{array}{c}0.032 * * * \\
(2.62)\end{array}$ & $\begin{array}{c}0.023 * * \\
(1.99)\end{array}$ & $\begin{array}{l}-0.006 \\
(0.60)\end{array}$ & $\begin{array}{l}-0.002 \\
(0.82)\end{array}$ \\
\hline Schooling & $\begin{array}{r}-0.028 \\
(1.31)\end{array}$ & $\begin{array}{l}-0.017 \\
(0.89)\end{array}$ & $\begin{array}{l}-0.013 \\
(0.68)\end{array}$ & $\begin{array}{r}-0.005 \\
(0.99)\end{array}$ \\
\hline Years worked & $\begin{array}{l}0.000 \\
(0.01)\end{array}$ & $\begin{array}{l}-0.005 \\
(0.25)\end{array}$ & $\begin{array}{l}-0.031 \\
(1.33)\end{array}$ & $\begin{array}{c}-0.015^{* *} \\
(2.26)\end{array}$ \\
\hline Math score & $\begin{array}{l}-0.023 \\
(1.55)\end{array}$ & $\begin{array}{l}-0.021 \\
(1.51)\end{array}$ & $\begin{array}{l}-0.014 \\
(1.15)\end{array}$ & $\begin{array}{c}-0.007^{*} \\
(1.95)\end{array}$ \\
\hline Risk Averse & $\begin{array}{c}-0.073^{*} \\
(1.77)\end{array}$ & $\begin{array}{l}-0.064 \\
(1.65)\end{array}$ & $\begin{array}{l}0.025 \\
(0.86)\end{array}$ & $\begin{array}{l}0.002 \\
(0.27)\end{array}$ \\
\hline Competitive & $\begin{array}{l}-0.106 \\
(1.02)\end{array}$ & $\begin{array}{l}-0.073 \\
(0.77)\end{array}$ & $\begin{array}{l}0.047 \\
(0.44)\end{array}$ & $\begin{array}{l}0.009 \\
(0.38)\end{array}$ \\
\hline Absolute overconfidence & $\begin{array}{l}0.000 \\
(0.04)\end{array}$ & $\begin{array}{l}-0.002 \\
(0.41)\end{array}$ & $\begin{array}{l}0.000 \\
(0.01)\end{array}$ & $\begin{array}{l}-0.000 \\
(0.25)\end{array}$ \\
\hline Relative overconfidence & $\begin{array}{l}-0.031 \\
(0.50)\end{array}$ & $\begin{array}{l}-0.027 \\
(0.44)\end{array}$ & $\begin{array}{c}0.008 \\
(0.15)\end{array}$ & $\begin{array}{l}0.001 \\
(0.04)\end{array}$ \\
\hline \# HH members & $\begin{array}{c}0.086^{*} \\
(1.88)\end{array}$ & $\begin{array}{c}0.075^{*} \\
(1.81)\end{array}$ & $\begin{array}{c}0.071^{* *} \\
(1.99)\end{array}$ & $\begin{array}{l}0.014 \\
(1.23)\end{array}$ \\
\hline Frequency of payment & $\begin{array}{l}0.381 \\
(1.30)\end{array}$ & $\begin{array}{l}0.346 \\
(1.25)\end{array}$ & $\begin{array}{l}-0.211 \\
(0.97)\end{array}$ & $\begin{array}{l}0.008 \\
(0.14)\end{array}$ \\
\hline
\end{tabular}

Note) Above presents coefficients on interaction terms between a dummy variable which equals to 1 if the respondent is in the Cut Flower sector and respective characteristics. Each coefficient is from separate regression. Independent variables included in estimation but not reported here are: wereda-level population of CF workers, wereda-level working population, age, female dummy, years of schooling, years worked here, math score, \# HH members, risk averse, competitive, overconfidence, hours worked per month, frequency of payment, and whether hired. All includes zone fixed effects. Robust t-statistics in parentheses. ${ }^{*} p<0.1 ; * * p<0.05 ; * * * p<0.01$. 
Table 11: Heterogeneous Effects of Cut Flower on Job Satisfaction (Inverse P-score weighting regression, Treatment effect on the treated, Trimmed sample)

\begin{tabular}{|c|c|c|c|c|c|c|}
\hline & $\begin{array}{l}\text { Income } \\
\text { level }\end{array}$ & Stability & $\begin{array}{l}\text { Work } \\
\text { type }\end{array}$ & $\begin{array}{l}\text { Future } \\
\text { Prospect }\end{array}$ & $\begin{array}{c}\text { Self } \\
\text { independ } \\
\text { ence }\end{array}$ & Total \\
\hline \multicolumn{7}{|l|}{ CF dummy $\mathrm{x}$ : } \\
\hline Female & $\begin{array}{l}0.051 \\
(0.15)\end{array}$ & $\begin{array}{l}0.015 \\
(0.05)\end{array}$ & $\begin{array}{l}-0.046 \\
(0.11)\end{array}$ & $\begin{array}{l}0.430 \\
(1.13)\end{array}$ & $\begin{array}{l}-0.359 \\
(0.96)\end{array}$ & $\begin{array}{l}0.090 \\
(0.07)\end{array}$ \\
\hline Age & $\begin{array}{l}-0.001 \\
(0.05)\end{array}$ & $\begin{array}{l}0.001 \\
(0.06)\end{array}$ & $\begin{array}{l}0.017 \\
(0.77)\end{array}$ & $\begin{array}{c}-0.043 * \\
(1.89)\end{array}$ & $\begin{array}{l}-0.020 \\
(0.87)\end{array}$ & $\begin{array}{l}-0.045 \\
(0.57)\end{array}$ \\
\hline Schooling & $\begin{array}{l}-0.035 \\
(0.90)\end{array}$ & $\begin{array}{l}-0.025 \\
(0.61)\end{array}$ & $\begin{array}{l}-0.066 \\
(1.36)\end{array}$ & $\begin{array}{l}-0.003 \\
(0.06)\end{array}$ & $\begin{array}{l}0.003 \\
(0.07)\end{array}$ & $\begin{array}{l}-0.127 \\
(0.78)\end{array}$ \\
\hline Years worked & $\begin{array}{l}-0.031 \\
(0.64)\end{array}$ & $\begin{array}{l}-0.036 \\
(0.82)\end{array}$ & $\begin{array}{l}0.008 \\
(0.13)\end{array}$ & $\begin{array}{c}-0.105^{* *} \\
(2.17)\end{array}$ & $\begin{array}{l}-0.023 \\
(0.38)\end{array}$ & $\begin{array}{l}-0.186 \\
(1.03)\end{array}$ \\
\hline Math score & $\begin{array}{c}-0.045^{*} \\
(1.69)\end{array}$ & $\begin{array}{l}-0.036 \\
(1.27)\end{array}$ & $\begin{array}{l}-0.017 \\
(0.51)\end{array}$ & $\begin{array}{l}0.024 \\
(0.70)\end{array}$ & $\begin{array}{l}-0.010 \\
(0.34)\end{array}$ & $\begin{array}{l}-0.083 \\
(0.73)\end{array}$ \\
\hline Risk Averse & $\begin{array}{c}0.192 * * * \\
(2.74)\end{array}$ & $\begin{array}{c}0.163^{* *} \\
(2.30)\end{array}$ & $\begin{array}{l}0.030 \\
(0.34)\end{array}$ & $\begin{array}{l}0.085 \\
(0.94)\end{array}$ & $\begin{array}{c}0.143^{*} \\
(1.80)\end{array}$ & $\begin{array}{c}0.613 * * \\
(2.15)\end{array}$ \\
\hline Competitive & $\begin{array}{r}-0.309 \\
(1.51)\end{array}$ & $\begin{array}{l}-0.301 \\
(1.63)\end{array}$ & $\begin{array}{l}0.155 \\
(0.66)\end{array}$ & $\begin{array}{l}-0.327 \\
(1.42)\end{array}$ & $\begin{array}{c}-0.405^{*} \\
(1.74)\end{array}$ & $\begin{array}{l}-1.187 \\
(1.47)\end{array}$ \\
\hline $\begin{array}{c}\text { Absolute } \\
\text { overconfidence }\end{array}$ & $\begin{array}{l}0.013 \\
(1.22)\end{array}$ & $\begin{array}{l}0.015 \\
(1.21)\end{array}$ & $\begin{array}{l}-0.000 \\
(0.02)\end{array}$ & $\begin{array}{l}-0.012 \\
(0.98)\end{array}$ & $\begin{array}{l}-0.010 \\
(0.98)\end{array}$ & $\begin{array}{l}0.005 \\
(0.12)\end{array}$ \\
\hline Relative & -0.135 & -0.139 & 0.005 & -0.065 & -0.120 & -0.455 \\
\hline overconfidence & $(1.17)$ & $(1.26)$ & $(0.04)$ & $(0.49)$ & $(1.02)$ & $(0.98)$ \\
\hline \# HH members & $\begin{array}{l}-0.045 \\
(0.53)\end{array}$ & $\begin{array}{c}-0.157^{*} \\
(1.97)\end{array}$ & $\begin{array}{l}0.132 \\
(1.35)\end{array}$ & $\begin{array}{l}-0.014 \\
(0.14)\end{array}$ & $\begin{array}{l}-0.026 \\
(0.30)\end{array}$ & $\begin{array}{l}-0.110 \\
(0.31)\end{array}$ \\
\hline Freq. of payment & $\begin{array}{c}0.908^{* *} \\
(2.00)\end{array}$ & $\begin{array}{l}0.762^{*} \\
(1.81)\end{array}$ & $\begin{array}{l}0.664 \\
(1.40)\end{array}$ & $\begin{array}{l}0.244 \\
(0.43)\end{array}$ & $\begin{array}{l}-0.364 \\
(0.57)\end{array}$ & $\begin{array}{l}2.214 \\
(1.16)\end{array}$ \\
\hline
\end{tabular}

Note) Above presents coefficients on interaction terms between a dummy variable which equals to 1 if the respondent is in the Cut Flower sector and respective characteristics. Each coefficient is from separate regression. Independent variables included in estimation but not reported here are: wereda-level population of CF workers, wereda-level working population, age, female dummy, years of schooling, years worked here, math score, \# HH members, risk averse, competitive, overconfidence, hours worked per month, frequency of payment, and whether hired. All includes zone fixed effects. Robust t-statistics in parentheses. ${ }^{*} p<0.1 ; * * p<0.05 ; * * * p<0.01$. 


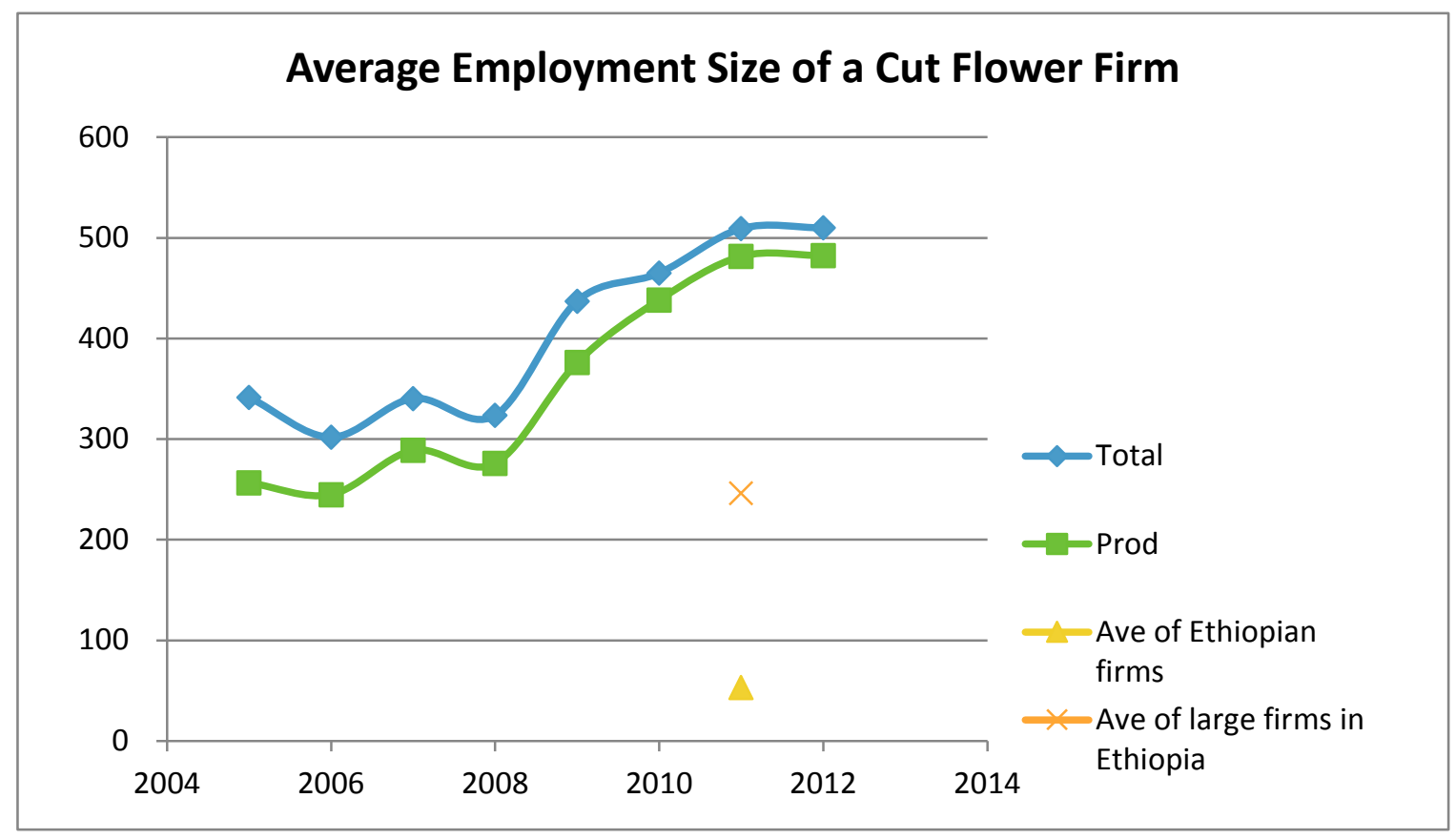

Figure 1. Number of workers employed in the cut flower sector

\begin{tabular}{|c|c|c|c|c|}
\hline & Project A & Pro & ct $B$ & $A$ or $B$ ? \\
\hline & You obtain for sure: & $50 \%$ chance of obtaining: & $50 \%$ chance of obtaining & \\
\hline RG1 & 1 Birr & 8 Birr & 0 Birr & \\
\hline RG2 & 2 Birr & 8 Birr & 0 Birr & \\
\hline RG3 & 3 Birr & 8 Birr & 0 Birr & \\
\hline RG4 & 4 Birr & 8 Birr & 0 Birr & \\
\hline RG5 & 5 Birr & 8 Birr & 0 Birr & \\
\hline RG6 & 6 Birr & 8 Birr & 0 Birr & \\
\hline RG7 & 7 Birr & 8 Birr & 0 Birr & \\
\hline RG8 & 8 Birr & 8 Birr & 0 Birr & \\
\hline
\end{tabular}

Figure 2. Payoff of the risk preference game 


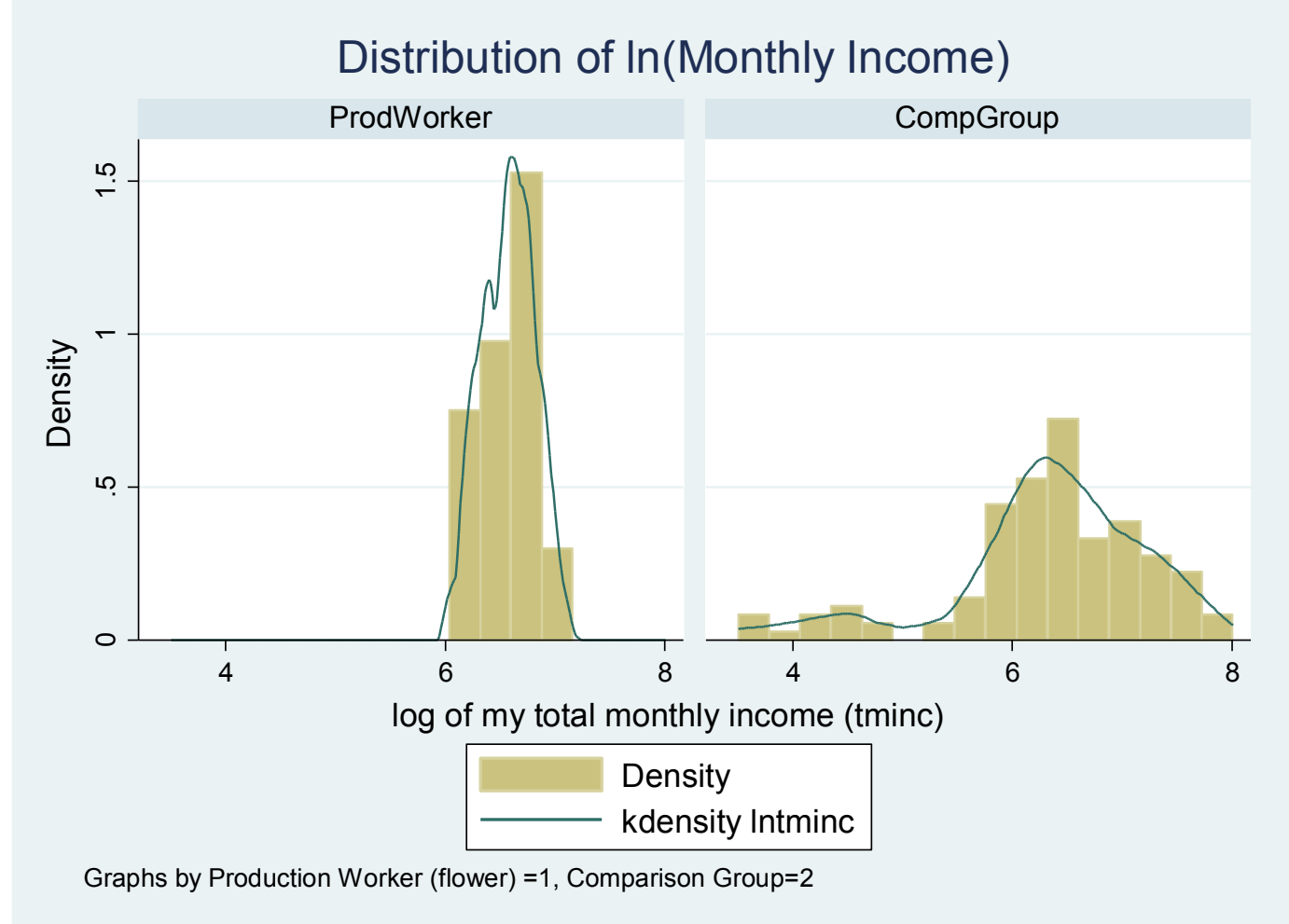

Figure 3. Distribution of log of yearly income by group

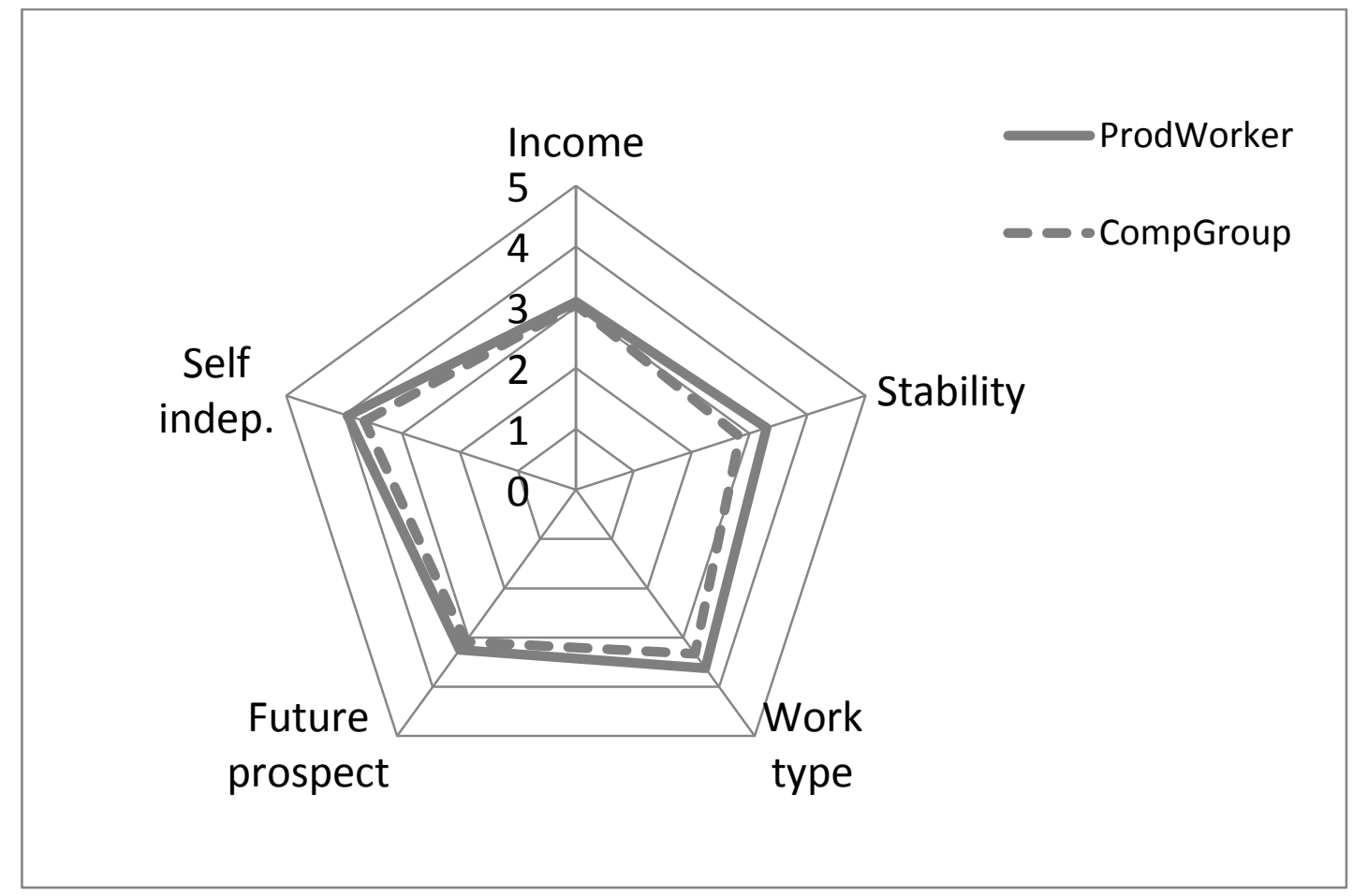

Figure 4. Means of subjective valuation of work by group 
Figure 5. Balancing test: Propensity scores by group

Histogram of Propensity Scores by Groups

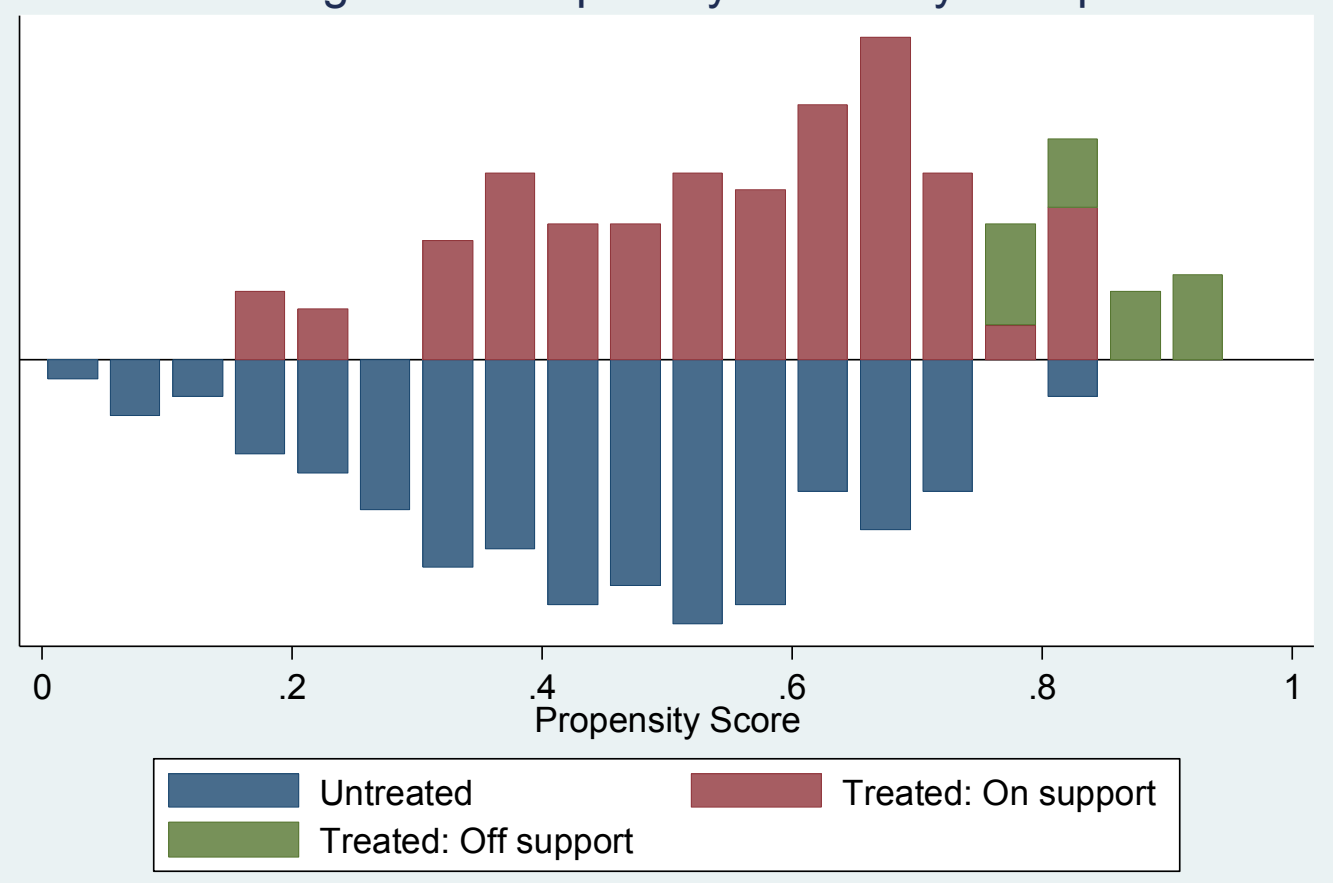

